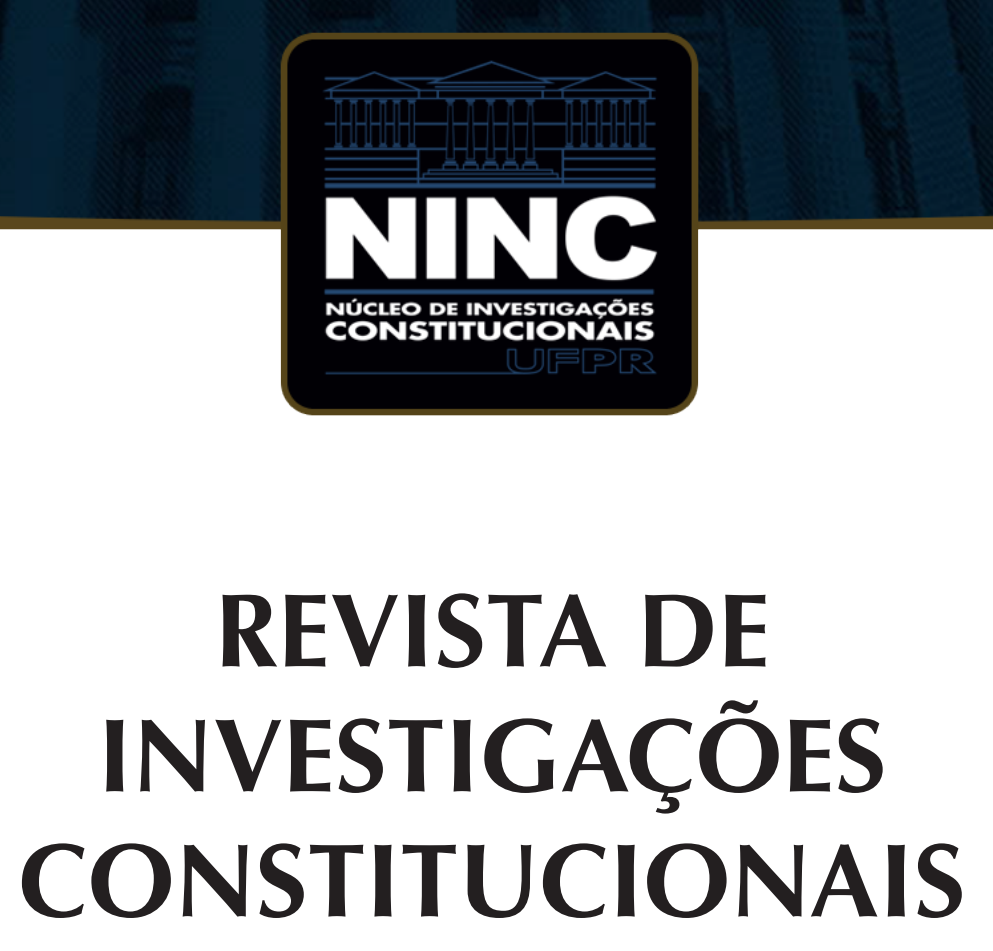

JOURNAL OF CONSTITUTIONAL RESEARCH

vol. 5 | n. 1 | janeiro/abril 2018 | ISSN 2359-5639 | Periodicidade quadrimestral Curitiba | Núcleo de Investigações Constitucionais da UFPR | www.ninc.com.br 


\title{
Uma década de audiências públicas no Supremo Tribunal Federal (2007-2017)*
}

\section{A decade of public hearings in the Supreme Federal Tribunal (2007-2017)}

\author{
FERNANDO LEAL** \\ Fundação Getúlio Vargas - FGV Direito Rio (Brasil) \\ fernando.leal@fgv.br \\ RACHEL HERDY*** \\ Universidade Federal do Rio de Janeiro (Brasil) \\ http://orcid.org/0000-0003-0210-3567 \\ rachelherdy@direito.ufrj.br \\ JÚLIA MASSADAS**** \\ Fundação Getúlio Vargas - FGV Direito Rio (Brasil) \\ http://orcid.org/0000-0001-8775-9009 \\ juliamassadas@gmail.com
}

Recebido/Received: 14.11.2017 / November 11th, 2017 Aprovado/Approved: 31.12.2017 / December 31st, 2017

\begin{abstract}
Como citar esse artigo/How to cite this article: LEAL, Fernando; HERDY, Rachel; MASSADAS, Júlia. Uma década de audiências públicas no Supremo Tribunal Federal (2007-2017). Revista de Investigações Constitucionais, Curitiba, vol. 5, n. 1, p. 331-372, jan./abr. 2018. DOI: 10.5380/rinc.v5i1.56328.

* Este artigo é resultado de um projeto de pesquisa interinstitucional desenvolvido no âmbito dos grupos de pesquisa Argumentação Jurídica, Instituições e Aspectos Constitucionais da Regulação (FGV Direito Rio) e Grupo de Pesquisa sobre Epistemologia Aplicada aos Tribunais (Programa de Pós-Graduação em Direito da Universidade Federal do Rio de Janeiro), e contou com uma bolsa do Programa Institucional de Bolsas de Iniciação Científica (PIBIC/CNPq). Além dos autores, participaram do levantamento de dados os seguintes pesquisadores: Ana Carolina Rezende, Ana Maria Côrrea, Andressa Carvalho, Luís Guilherme Reis, Maria Mello Franco e Vanessa Tourinho.

** Professor da FGV Direito Rio (Rio de Janeiro, RJ, Brasil). Doutor em Direito pela Christian-Albrechts-Universität zu Kiel. Doutor e Mestre em Direito Público pela Universidade do Estado do Rio de Janeiro (UERJ). Coordenador do Mestrado em Direito da Regulação da FGV Direito Rio. E-mail: fernando.leal@fgv.br.

*** Professora Permanente do Programa de Pós-Graduação em Direito da Universidade Federal do Rio de Janeiro (Rio de Janeiro, RJ, Brasil). Doutora em Sociologia pela Universidade do Estado do Rio de Janeiro. Atualmente é Investigadora Visitante no Laboratório de Argumentação (ArgLab) do Instituto de Filosofia da Universidade Nova de Lisboa (Pós-Doutorado). Líder do Grupo de Pesquisa sobre Epistemologia Aplicada aos Tribunais (GREAT).E-mail: rachelherdy@direito.ufrj.br.

**** Mestranda em Direito da Regulação pela Fundação Getúlio Vargas (Rio de Janeiro, RJ, Brasil). Bolsista da CAPES e da FGV. Assistente de pesquisa da FGV Direito Rio. Membro dos Grupos de Pesquisas sobre Epistemologia Aplicada aos Tribunais (GREAT) e Argumentação Jurídica, Instituições e Aspectos Constitucionais da Regulação. E-mail: juliamassadas@gmail.com.
\end{abstract}


Resumo

O presente artigo oferece um balanço dos últimos dez anos de audiências públicas no Supremo Tribunal Federal do Brasil. Argumenta-se que, durante esse tempo, o instituto foi utilizado de maneira incoerente e inconsistente. A incoerência diz respeito especialmente à tentativa de atribuir ao instituto das audiências públicas a função de legitimidade democrática. Essa associação entre audiência pública e democracia pode ser criticada com base em razões normativas, referentes ao direito positivo, e conceituais. A inconsistência, por sua vez, está relacionada à operacionalização desparametrizada do instituto. Essa segunda conclusão será argumentada com a ajuda de um conjunto de análises majoritariamente quantitativas.

Palavras-chave: audiências públicas; jurisdição constitucional; legitimidade democrática; justificação epistêmica; conhecimento científico.

\section{Abstract}

The present article offers an assessment of the last 10 years of public hearings in the Brazilian Supreme Federal Tribunal. It is argued that, during this period, the institute has been employed in an incoherent and inconsistent manner. The incoherency refers especially to the attempt to attribute the function of democratic legitimacy to the institute of public hearings. This association between public hearings and democracy can be criticized on the basis of normative reasons, with respect to the positive law, and conceptual reasons. On the other hand, the inconsistency refers to the unstandardized operationalization of the institute. This second conclusion will be argued with the help of a set of mostly quantitative analysis.

Keywords: public hearings; judicial review; democratic legitimacy; epistemic justification; scientific knowledge.

\section{SUMÁRIO}

1. Introdução; 2. Para quê servem as audiências públicas? 2.1. O que diz o direito positivo?; 2.2. Por que a legitimidade democrática não importa? 3. Um balanço sobre as audiências públicas; 3.1 Questões metodológicas; $\mathbf{3 . 2}$ O que dizem os dados; 4. Conclusão; 5. Referências.

\section{INTRODUÇÃO}

Em 2017, completam-se 10 anos de audiências públicas no Supremo Tribunal Federal brasileiro (STF). Tais audiências foram previstas como um mecanismo de consulta a especialistas para o esclarecimento de matéria ou circunstância de fato. Sua previsão consta de duas leis ordinárias aprovadas em 1999 (Lei 9.868 e Lei 9.882), as quais têm como objetivo dispor sobre os principais mecanismos de controle abstrato de constitucionalidade no direito brasileiro. Em 2007, quando foi realizada a primeira audiência, não havia regulamentação específica sobre o procedimento a ser seguido para a sua realização. Neste vácuo normativo, o então ministro Carlos Ayres Britto, relator do primeiro caso, invocou a aplicação dos parâmetros sobre audiências públicas previstos no Regimento Interno da Câmara dos Deputados. Dois anos depois, com a Emenda Regimental no. 29/2009, o Regimento Interno do tribunal foi alterado e passou a prever dispositivos específicos sobre a forma de convocação e as matérias objeto de audiências públicas. A partir de então, ampliou-se a possibilidade de sua convocação para toda e qualquer classe processual. Iniciamos o segundo semestre de 2017, uma década após a realização da primeira audiência, com o marco de 22 audiências públicas convocadas e realizadas.

O objetivo deste artigo é apresentar uma análise das audiências públicas no STF durante a última década (2007-2017). Os dados levantados até o presente indicam que 
este mecanismo de consulta a especialistas tem sido utilizado de forma inconsistente e incoerente. Por "inconsistente", entendemos uma ação ou comportamento que difere em face de circunstâncias semelhantes. A "inconsistência" refere-se não a uma ação em particular, de um específico ministro, mas ao conjunto de ações ou práticas da corte como uma instituição ao longo da última década. Como pretendemos evidenciar, não existe consistência tanto no que diz respeito à convocação das audiências públicas, como critérios de admissibilidade e natureza da questão a ser esclarecida, como aspectos específicos referentes ao procedimento de consulta e deferência aos especialistas. Em se tratando de uma prática judicial, a consistência emerge como um problema de igualdade e, no limite, como uma questão de justiça. Já o termo "incoerente" é aqui utilizado em um sentido pragmático, e não lógico-formal. Do mesmo modo, aplicamos este conceito ao pensamento da corte como uma instituição, manifestado na fala e na escrita de seus respectivos ministros. Por "incoerente", entendemos aquele pensamento que exprime uma tensão, isto é, duas ou mais ideias que apontam em direções opostas ou que se comprometem com valores irreconciliáveis. Como pretendemos argumentar, é incoerente, pelas razões normativas e conceituais que expomos, atribuir uma função de legitimação democrática às audiências públicas que pretendem recorrer aos esclarecimentos de especialistas sobre questões de fato. A partir daí, pontuamos uma sequência de incoerências adicionais: a utilização deste mecanismo para o esclarecimento de questões de direito exclusivamente; a autorização para a participação de advogados quando os ministros são presumidamente especialistas em questões de direito; o conflito de interesses que se revela em relação a alguns dos participantes habilitados; a ausência de um procedimento dialético que permita um uso não-falacioso do argumento de autoridade; etc.

Este artigo está dividido em duas partes. A primeira parte, que podemos chamar de teórico-analítica, consiste na apresentação de questões normativas e conceituais sobre a dupla função das audiências públicas. Antes de expormos os dados propriamente ditos, e para que possamos justificar as nossas conclusões, iniciamos com considerações sobre o que diz o direito positivo em relação às audiências públicas e por que razão o ideal de legitimidade democrática parece fora de lugar no presente contexto. A segunda parte, que podemos chamar de empírica, está dedicada à apresentação, por meio de gráficos e tabelas, dos dados levantados até o momento. Enquanto a crítica teórico-analítica que formulamos na primeira parte à dupla função das audiências públicas - política e epistêmica - será importante para justificar a conclusão de que este mecanismo tem sido utilizado de modo incoerente, os dados apresentados na segunda parte são indicativos do seu uso inconsistente. A falta de coerência e consistência na utilização deste importante mecanismo de consulta a especialistas comprometeram nos últimos anos o grau de justificação das decisões da corte. 
O conjunto de dados que apresentamos é de natureza basicamente quantitativa. Análises qualitativas foram eventualmente realizadas, em relação a alguns casos específicos, com o objetivo de corroborar nossas hipóteses interpretativas. Vale observar que o universo analisado não é composto por todos os casos julgados no STF que envolvem a discussão de matéria ou circunstância de fato técnica ou científica. Podemos supor que este seria um universo relativamente maior do que o universo de casos para os quais as audiências públicas foram convocadas. Isto porque os ministros relatores de casos cuja solução exige algum tipo de esclarecimento técnico ou científico nem sempre optam pela realização de uma audiência pública. As próprias leis (9.868/99 e 9.882/99) que instituíram o mecanismo da audiência pública no julgamento das ações perante o STF e o Regimento Interno deste tribunal preveem outras alternativas, como designar perito ou comissão de peritos para que emita parecer sobre a questão' ${ }^{\text {. Tam- }}$ bém é possível que certos casos que demandam a discussão de matéria ou circunstância técnica ou científica sequer sejam remetidos a qualquer autoridade epistêmica, sendo resolvidos por meio de pesquisas independentes feitas pelos próprios julgadores e seus assessores. Portanto, casos como a Ação Cautelar 4081, a respeito da obrigatoriedade de fornecimento da substância Fosfoetanolamina, em que o ministro Lewandowski optou por requisitar parecer ao Instituto Nacional do Câncer (INCA), embora tenha efetivamente engajado a comunidade de técnicos e cientistas, não será objeto de nossa análise. O mesmo se aplica a casos como o Recurso Extraordinário n 635.659, sobre a criminalização da posse de drogas para consumo pessoal. ${ }^{2}$ Embora muitas informações técnicas e científicas tenham sido oferecidas no plenário do tribunal pelos amici curiae, e também de forma independente pelos próprios ministros para embasar suas decisões, não foi realizada qualquer forma de consulta a especialistas prevista no Regimento Interno.

\section{PARA QUÊ SERVEM AS AUDIÊNCIAS PÚBLICAS?}

Durante os dez anos de funcionamento real do instituto, consolidou-se a visão de que as audiências públicas cumprem na prática decisória do STF uma dupla função. Por um lado, as audiências municiam os ministros com informações próprias do domínio científico consideradas cruciais para a solução jurídica de um determinado problema. Nesse aspecto, as audiências servem ao objetivo de compensar déficits epistêmicos de tomadores de decisão que precisam determinar como o direito deve lidar com

\footnotetext{
1 Em favor da convocação de uma comissão de peritos para lidar com o problema de determinação dos possíveis impactos econômicos associados a uma eventual declaração de inconstitucionalidade de planos econômicos pelo STF, cf. LEAL, Fernando. Os Impactos dos planos econômicos e a encruzilhada do Supremo. In: Joaquim Falcão, Diego Werneck Arguelhes e Felipe Recondo (Org.). Onze Supremos: O Supremo em 2016. Belo Horizonte: Letramento, 2016, p. 92-95.

2 V. ARGUELHES, Diego Werneck e LEAL, Fernando. Por que só maconha? In: Joaquim Falcão, Diego Werneck Arguelhes e Felipe Recondo (Org.). O Supremo em 2015. Rio de Janeiro: Escola de Direito do Rio de Janeiro da Fundação Getulio Vargas, 2016, p. 331-334.
} 
problemas que não são propriamente jurídicos. Por outro lado, as audiências públicas são vistas como mecanismos de acesso e de participação da sociedade civil na corte.

Nessa última dimensão, o papel desempenhado pelas audiências públicas no STF não difere do papel que as audiências públicas desempenham em outros contextos, como no processo decisório das Agências Reguladoras ou nas casas do Congresso Nacional ${ }^{3}$. Ainda, a maneira como as audiências públicas tem sido empregadas aproxima-as de outro instituto, o amicus curiae, pois ambos são compreendidos como formas compensar déficits democráticos de um órgão integrado por membros não eleitos capazes de invalidar decisões majoritárias.

Não é raro, nesse contexto, vincular-se a importância das audiências públicas na jurisdição constitucional brasileira com o mote da "sociedade aberta dos intérpretes da Constituição", de Peter Häberle. O entendimento de Gilmar Mendes, idealizador do projeto de lei que resultou na criação do instituto das audiências públicas no âmbito da jurisdição constitucional, é exemplar. Na passagem a seguir, podemos perceber não só a dupla função - política e epistêmica - atribuída ao instituto, com referência direta ao pensamento de Häberle, como a aproximação que se faz entre a figura do especialista e os amigos da corte:

A propósito, Peter Häberle defende a necessidade de que os instrumentos de informação dos juízes constitucionais sejam ampliados, especialmente no que se refere às audiências públicas e às 'intervenções de eventuais interessados', assegurando-se novas formas de participação das potências públicas pluralistas enquanto intérpretes em sentido amplo da Constituição [...]. Ao ter acesso a essa pluralidade de visões em permanente diálogo, este Supremo Tribunal Federal passa a contar com os benefícios decorrentes dos subsídios técnicos, implicações político-jurídicas e elementos de repercussão econômica que possam vir a ser apresentados pelos "amigos da Corte".4

Essa dupla dimensão adquirida pelas audiências é facilmente corroborada por uma série de escritos doutrinários sobre o assunto e pelas falas dos ministros do STF.

Lacombe, Legale e Johann, por exemplo, propõem a existência de dois modelos de audiência pública. 5 O primeiro, mais voltado para a consulta a participantes sem

\footnotetext{
3 No caso específico da legitimação democrática da atuação das Agências Reguladoras v., por exemplo, ARAGÃO, Alexandre. A Legitimação Democrática das Agências Reguladoras. In: Gustavo Binenbojm (Org.). Agências Reguladoras e Democracia. Rio de Janeiro: Lumen Juris, 2006, p. 1-20. Sustenta o autor: “Com efeito, o principal mecanismo de legitimação democrática da Administração Pública é o da participação dos titulares dos interesses individuais, coletivos e difusos através de audiências e consultas públicas prévias à edição dos atos normativos que possam afetar os seus interesses" (p. 11).

4 BRASIL. Ação Direta de Inconstitucionalidade no 3.510/DF. Reqte. Procurador-geral da República. Reqdo. Congresso Nacional. Relator: Min. Carlos Ayres Britto. Disponível em <http://redir.stf.jus.br/paginadorpub/paginador.jsp?docTP=AC\&do$\mathrm{CID}=611723>$. Acesso em 03 out. 2017. Inteiro teor, p. 274-275.

5 LACOMBE, Margarida; LEGALE, Siddharta; JOHANN, Rodrigo F. As Audiências Públicas no Supremo Tribunal Federal nos mode-
} 
perfil científico ou técnico, seria o modelo Gilmar Mendes; o segundo, mais voltado para a consulta a participantes com perfil cientifico e técnico, seria o modelo Fux. Enquanto o modelo Gilmar Mendes tende a debruçar-se sobre questões de forte apelo moral e político, o modelo Fux foca em questões de fato. Já o estudo de Valle et al, que resultou em um livro específico sobre o tema, ao reconhecer a natureza política das audiências públicas, critica o perfil técnico de alguns participantes por impedir a "efetiva oitiva da 'vontade' social acerca do tema"6. Em referência à audiência pública sobre células-tronco, Valle et al sustentam que "o pano de fundo do debate se relaciona a uma grave questão moral, cuja sensibilidade social não teve a rigor oportunidade para aflorar, à vista do recorte empreendido pelo Relator no que toca aos participantes do diálogo".7 A interpretação de Valle et al parece repercutir em grande parte dos estudos realizados: a natureza política das audiências não só é distinguida por meio de uma descrição da prática, como avaliada de modo positivo; e, a partir desta avaliação positiva da função de legitimação democrática das audiências públicas, são apresentadas críticas à sua forma de condução ${ }^{8}$. Contudo, não encontramos, nos estudos realizados até hoje, uma abordagem crítica, com base em pesquisa empírica, das incoerências e inconsistências na prática do STF9 9 . A dupla função das audiências públicas e a tensão entre democracia e ciência - dois pontos fundamentais do nosso estudo - não têm recebido a devida atenção.

Em referência às falas dos ministros, o ministro Marco Aurélio, por exemplo, posicionou-se no sentido de que a audiência pública é "um símbolo marcante, no Poder Judiciário, da própria democracia"10. Ao mesmo tempo, ressaltou que os juízes precisam contar com fatos e dados para um julgamento seguro, o que poderia sinalizar a compreensão de que as audiências possuem uma dimensão de compensação de déficits

Ios Gilmar Mendes e Luiz Fux: a legitimação técnica e o papel do cientista no laboratório de precedentes. In: VIEIRA, José Ribas, VALLE, Vanice Lírio do, MARQUES, Gabriel Lima (Orgs.). Democracia e suas Instituições. Rio de Janeiro: Imo's, 2014.

6 VALLE, Vanice Regina Lírio do et al. Audiências públicas e ativismo: diálogo social no STF. Belo Horizonte: Fórum, 2012, p. 69. No mesmo sentido, v. MARONA, Marjorie Corrêa; ROCHA, Marta Mendes da. Democratizar a jurisdição constitucional? O caso das audiências públicas no Supremo Tribunal Federal. Revista de Sociologia e Política, v. 26, n. 62, p. 131-156, jan. 2017, p. 152.

7 Idem. p. 67

8 Destacamos: CARVALHO, Flávia Martins de. Audiências Públicas no Supremo Tribunal Federal: uma alternativa democrática? Dissertação (Mestrado em Direito) - Universidade Federal do Rio de Janeiro, Centro de Ciências Jurídicas e Econômicas, Faculdade de Direito, 2011;VESTENA, Carolina Alves. Audiências públicas: diagnóstico empírico sobre os limites da participação social. Revista Brasileira de Estudos Constitucionais - RBEC, Belo Horizonte, ano 6, n. 24, p. 973-1020, out./dez., 2012.

9 Cf. MARONA, Marjorie Corrêa; ROCHA, Marta Mendes da. Democratizar a jurisdição constitucional? O caso das audiências públicas no Supremo Tribunal Federal. Revista de Sociologia e Política, v. 26, n. 62, p. 131-156, jan. 2017. Neste estudo, é feito um levantamento de dados em muitos aspectos semelhante àquele que apresentamos neste artigo. As autoras, contudo, parecem tomar como certo, do ponto de vista normativo, o caráter político de legitimação democrática das audiências públicas - embora façam críticas à concreta limitação da deliberação entre os atores participantes.

10 BRASIL. Supremo Tribunal Federal. Notas taquigráficas da audiência pública na Ação Direta de Inconstitucionalidade n 3.937/SP. Dispõe sobre a proibição do uso de amianto. Disponível em <http://www.Supremo.jus.br/arquivo/cms/ProcessosAudienciasPublicasAcoesAmianto/anexo/Transcricoes_Audiencia_sobre_Amianto_Texto_consolidado.pdf $>$, p. 486. Acesso em 26 out. 2016. 
epistêmicos ${ }^{11}$. O ministro Gilmar Mendes - que, como vimos acima, foi o idealizador do projeto de lei que resultou na criação do instituto no direito brasileiro - exaltou o seu caráter democrático, sugerindo que o STF seria uma "[c]asa do povo, tal qual o parlamento".12 O ministro Luiz Fux, por sua vez, destacou a legitimação democrática das decisões judiciais, garantida através da participação do cidadão nas audiências públicas. ${ }^{13}$ Em outra ocasião, contudo, afirmou que se sentia "perfeitamente habilitado a decidir" a causa em questão, afastando ressalvas de que juízes, por não possuírem informação e/ ou conhecimento específico sobre aspectos técnico-científicos complexos, não seriam os árbitros mais qualificados para a tomada de decisão. ${ }^{14}$

Esses são apenas alguns exemplos de manifestações acerca do propósito das audiências públicas, mas que representam uma concepção do instituto que parece ser compartilhada por estudiosos do direito e pelos ministros do STF de uma forma geral. O amplo consenso estabelecido nesses dez anos em torno dos papéis de legitimação democrática e de justificação epistêmica desempenhado pelas audiências públicas obscurece, contudo, problemas mais profundos sobre a sua justificação. Dois merecem especial destaque. O primeiro diz respeito à própria compatibilidade da função dúplice atribuída às audiências públicas com o direito positivo. $\mathrm{O}$ segundo refere-se à possibilidade de harmonização conceitual entre democracia e conhecimento.

\subsection{O que diz o direito positivo?}

O instituto da audiência pública está previsto na Lei 9.868 de 1999 - que dispõe sobre o processo e julgamento da Ação Direta de Inconstitucionalidade (ADI) e da Ação Declaratória de Constitucionalidade (ADC) perante o STF - e na Lei 9.882 de 1999, que trata do processo e julgamento da Arguição de Descumprimento de Preceito Fundamental (ADPF), nos termos do §10 do art. 102 da Constituição Federal. Dez anos após a promulgação das referidas leis, a Emenda Regimental 29/2009 acrescentou dispositivos sobre a matéria ao Regimento Interno do STF. Foram introduzidos os incisos XVII e XVIII, no art. 13, e o inciso III e o parágrafo único, no art. 154, permitindo assim a sua

\footnotetext{
11 As manifestações foram realizadas na mesma audiência pública.

12 BRASIL. Supremo Tribunal Federal. Ação Direta de Inconstitucionalidade n 3.510/DF. Reqte. Procurador-geral da República. Reqdo. Congresso Nacional. Relator: Min. Carlos Ayres Britto. Disponível em <http://redir.Supremo.jus.br/paginadorpub/paginador.jsp?docTP=TP\&docID=583645\#87\%20-\%20AC\%D3RD\%C3O\%20-\%20improcedente>, p. 465. Acesso em 27 out. 2016.

13 Entrevista concedida pelo ministro Luiz Fux à TV Justiça. Disponível em <https://www.youtube.com/watch?v=GtNGR1zhEyc\&index=1\&list=PLippyY19Z47vSUdzoXYw4mNEclkHMKVaa>. Acesso em 28 out. 2016. O ministro afirmou que: "[e]ssas audiências públicas, elas permitem que o cidadão no exercício pleno da cidadania contribua para que uma solução judicial seja legitimada democraticamente porque o grande trunfo da decisão de uma Suprema Corte é obter confiança do povo. Essa é a grande arma do Judiciário: é a confiança do povo". Transcrição própria.
}

14 BRASIL. Supremo Tribunal Federal. Notas taquigráficas da audiência pública nas Ações Diretas de Inconstitucionalidade no 4901, 4902, 4903 e 4937. Dispõe sobre o Novo Código Florestal. Disponível em <http://www.Supremo.jus.br/arquivo/cms/ audienciasPublicas/anexo/TranscriesNovoCdigoFlorestal.pdf>, p. 171. Acesso em 21 set. 2017. 
convocação para todo tipo de ação julgada neste tribunal. Vejamos o que dizem estes dispositivos.

A Lei 9.868/99 prevê nos artigos 90, $\S 1^{\circ}$ (para ADI) e 20, § $1^{\circ}$ (para ADC), com idêntica redação, que:

Em caso de necessidade de esclarecimento de matéria ou circunstância de fato ou de notória insuficiência das informações existentes nos autos, poderá o relator requisitar informações adicionais, designar perito ou comissão de peritos para que emita parecer sobre a questão, ou fixar data para, em audiência pública, ouvir depoimentos de pessoas com experiência e autoridade na matéria15.

Com redação análoga, retirando as menções à "matéria ou circunstância de fato" e à "notória insuficiência de informações", dispõe (para ADPF) o art. 60 §1 da Lei 9.882/99:

Se entender necessário, poderá o relator ouvir as partes nos processos que ensejaram a argüição, requisitar informações adicionais, designar perito ou comissão de peritos para que emita parecer sobre a questão, ou ainda, fixar data para declarações, em audiência pública, de pessoas com experiência e autoridade na matéria ${ }^{16}$.

Os incisos XVII, ambos dos artigos 13 e 21 do Regimento Interno do STF, retomam a disposição prevista na Lei 9.868/99 com referência à natureza fática da questão, e repetem o que está escrito nas duas disposições acima no que diz respeito à qualidade das pessoas a serem ouvidas durante a audiência pública ("com experiência e autoridade na matéria"). Mas o Regimento Interno vai além: acrescenta que as "questões ou circunstâncias de fato" devem ter repercussão geral e ser de interesse público relevante. Assim dispõe a redação comum dos artigos 13 (referente às atribuições do Presidente) e 21 (referente às atribuições do Relator):

São atribuições [...] XVII - convocar audiência pública para ouvir o depoimento de pessoas com experiência e autoridade em determinada matéria, sempre que entender

\footnotetext{
15 BRASIL. Lei № 9868/99. Dispõe sobre o processo e julgamento da ação direta de inconstitucionalidade e da ação declaratória de constitucionalidade perante o Supremo Tribunal Federal. Sancionada em 10 de novembro de 1999. Disponível em <http:// www.planalto.gov.br/ccivil_03/leis/L9868.htm> Acesso de 31 maio 2017.

16 BRASIL. Lei № 9882/99. Dispõe sobre o processo e julgamento da arguição de descumprimento de preceito fundamental, nos termos do $\S 10$ do art. 102 da Constituição Federal. Sancionada em 3 de dezembro de 1999. Disponível em <http://www. planalto.gov.br/ccivil_03/leis/19882.htm> Acesso em 31 maio.2017.
} 
necessário o esclarecimento de questões ou circunstâncias de fato, com repercussão geral e de interesse público relevante, debatidas no âmbito do Tribunal17.

O Regimento Interno do STF dispõe ainda, no parágrafo único do art. 21, que compete ao Relator convocar a audiência, de forma ampla e com a fixação de prazos para a indicação das pessoas; garantir a pluralidade das opiniões apresentadas; e selecionar os habilitados, organizando as falas. Indica ainda que a audiência será transmitida pela Rádio e TV Justiça, e que casos omissos serão deliberados pelo Ministro que convocar a audiência.

No sítio eletrônico do STF também é possível encontrar informações a respeito das audiências públicas que ecoam os dispositivos acima ${ }^{18}$. Mas o sítio eletrônico também vai além ao especificar que as pessoas a serem ouvidas são "especialistas em questões técnicas, científicas, administrativas, políticas, econômicas e jurídicas".

As referências relacionam as audiências públicas com expressões e palavras como "questões de fato", "especialistas", "experiência e autoridade em determinada matéria" e, nos casos específicos das Leis 9.868 e 9.882, com "peritos". Se o texto legal pode ser considerado um referencial minimamente importante para a identificação da norma que a ele está vinculada, no sentido de restringir hipóteses de compreensão do intérprete, não parece simples extrair dos dispositivos acima indicados que as audiências públicas são um espaço para ouvir manifestações de qualquer cidadão. Ao contrário, a dicção legislativa parece preocupada com a obtenção de informações de pessoas com algum tipo de conhecimento específico sobre determinado tema. Seletividade, e não inclusão, orientam a compreensão do texto. Nesse sentido, apenas um subconjunto da sociedade poderia ser considerado textualmente relevante para a permissão legislativa de convocação de uma audiência pública. ${ }^{19}$

Na mesma linha - embora, neste caso, haja expressa manifestação em sentido contrário no site do tribunal - parece questionável a compatibilidade entre o propósito de convocação de uma audiência pública e a oitiva de juristas no STF, independentemente do conhecimento e da autoridade que possam ter nas suas respectivas áreas de atuação. O requisito de "notório saber jurídico" inscrito no artigo 101 da Constituição Federal, a conformação real dos gabinetes dos ministros, dotados de assessores, e as possibilidades de pesquisa jurídica no desempenho das vocações institucionais

\footnotetext{
17 BRASIL. Regimento Interno do Supremo Tribunal Federal (STF). Brasília: STF, 2015. Disponível em <http://www.stf.jus.br/ arquivo/cms/legislacaoRegimentolnterno/anexo/RISTF.pdf> Acesso em 20 set. 2017. Na verdade, notamos que a redação não é exatamente idêntica. Enquanto o inciso XVII do artigo 13 fala em "repercussão geral $e$ interesse público relevante", o texto correspondente do artigo 21 fala em "repercussão geral ou interesse público relevante". Preciosismo; ou não.

18 As informações sobre audiências públicas no sítio eletrônico do STF estão disponíveis em <http://Supremo.jus.br/portal/ audienciaPublica/audienciaPublicaPrincipal.asp >.

19 No mesmo sentido, v. PINTO, Henrique Motta; ROSILHO, André Janjácomo. Qual é a função das audiências públicas do STF: a legitimidade democrática ou a legitimidade técnica? Sociedade Brasileira de Direito Público, 2009.
} 
da corte funcionariam como razões contrárias à necessidade de se obter informações jurídicas "adicionais" ou que não poderiam ser obtidas de outras maneiras pelos ministros. Tome-se como exemplo a convocação de audiência pública para discutir a compatibilidade do artigo 20 do Código Civil com a Constituição no conhecido caso das "biografias não autorizadas" (ADI 4815). O caso não envolvia qualquer discussão de fato ou conhecimento de outra área do saber relevante para a tomada de decisão, mas um problema, ainda que complexo, de manipulação de elementos do direito ou de teorias e metodologias de decisão jurídica. Nenhum conhecimento científico relevante estava em jogo. Por isso, não está claro no caso que as audiências produziram informações não previamente disponíveis aos ministros, e muito menos que é possível estabelecer alguma correlação entre a oitiva dos participantes da audiência e a justificação de cada voto. Assim, se parece crível que o legislador não abriu espaço para a presença de qualquer pessoa em uma audiência pública, é possível também concluir que, do subconjunto de atores relevantes a serem ouvidos, estão excluídos os "especialistas em questões jurídicas".

Por fim, um último ponto. Um leitor cauteloso poderia se perguntar: mas que matéria ou circunstância de fato é esta? As questões de fato esclarecidas em audiência pública não se confundiriam com matéria probatória? O que ocorreu com a Súmula 279 do STF, que prescreve que os recursos a serem analisados nesta instância não podem ter como pretensão o reexame de matéria probatória? Existiria algum tipo de questão de fato no processo judicial que não constitui matéria probatória? E quando estamos diante de ações de controle de constitucionalidade de caráter abstrato, que não têm como base uma violação de direito concreta e determinada, quais seriam os fatos a serem esclarecidos?

A dimensão fática da decisão judicial mais conhecida é certamente aquela que diz respeito aos chamados "fatos adjudicativos". Tais fatos são alegados pelas partes em litígio para provar questões particulares de um caso: quem fez o quê, onde, quando e (às vezes) por quê. Mas há uma outra dimensão da decisão judicial que igualmente envolve determinações fáticas, e que está em jogo no caso das audiências públicas no âmbito do exercício do controle de constitucionalidade por parte do STF. Esta segunda dimensão diz respeito aos "fatos legislativos", também chamados de "gerais".20 Alegações que concernem a esta segunda dimensão fática podem ser feitas pelas próprias partes, pelos ministros ou ainda por terceiros como especialistas e amici curiae; e não se direcionam a provar elementos particulares de um caso, mas oferecem razões de ordem empírica para uma decisão política: quê elementos de fato podem dar suporte

\footnotetext{
20 A discussão sobre fatos legislativos teve início com o artigo de DAVIS, Kenneth Culp. An Approach to Problems of Evidence in the Administrative Process. Harvard Law Review, Cambridge, v. 55, n. 1, p. 402-?, 1941-42. A bibliografia hoje é extensa. Ver, por todos, os trabalhos de David Faigman: "Normative Constitutional Fact-Finding". University of Pennsylvania Law Review, n. 139, 1991, p. 541-613; e Constitutional Fictions: A Unified Theory of Constitutional Facts. Oxford: Oxford University Press, 2008.
} 
à razoabilidade de uma medida legislativa? Tais fatos são chamados de "legislativos" porque correspondem ao tipo que legisladores consideram no processo de criação do direito.

Então - poder-se-ia dizer a esta altura: se a questão de fato é mesmo do tipo legislativo, pois diz respeito à criação do direito, não estaria justificada a convocação da audiência pública com o propósito de democratizar a decisão judicial? A resposta é negativa. Isso porque as questões que orientam a formulação de políticas públicas podem ser de dois tipos. Por um lado, representam preferências morais e políticas; mas, por outro, podem referir-se ou estar baseadas em premissas referentes a fatos do mundo, como os que envolvem, por exemplo, o potencial de certo produto para causar ou não certa enfermidade. Neste último caso, as questões que orientam a formulação de políticas públicas envolveriam descrições sobre aspectos do mundo real, e, como tais, não dependeriam da opinião pública para serem verdadeiras. Descrições são verdadeiras ou falsas independentemente do pensamento da maioria das pessoas. Aliás, com frequência, a opinião pública parece ignorar uma imensa parte das proposições que descrevem o mundo. Este é o argumento da seção seguinte.

\subsection{Por que a legitimidade democrática não importa?}

As indicações do direito positivo sobre o propósito das audiências públicas e sobre os limites da participação de integrantes da sociedade são reforçadas por um argumento conceitual. Se é possível objetar que a interpretação das disposições legais, por envolver algumas opções teórico-normativas sobre a tarefa de atribuição de sentido a textos, incluindo algum grau de formalismo, não leva necessariamente à redução do papel das audiências à superação de questões de fato e, assim, à construção de pontes entre o direito e a ciência, um olhar aproximado para as relações entre democracia e conhecimento, os dois compromissos comumente associados às audiências públicas, contribui para justificar a preferência pela diluição dessa aproximação. Assim, para além de discussões sobre a adequação de teorias e métodos de interpretação jurídica que possam favorecer leituras mais ou menos presas ao texto, permanece em aberto se a abertura à ampla participação da sociedade em debates que envolvem a compreensão e a decisão sobre questões que dependem do estágio de evolução do conhecimento científico é no mínimo compatível com o funcionamento da ciência. Com outras palavras, o que se pretende é defender que pode haver boas razões para separar institutos cujas funções são contribuir para lidar com carências epistêmicas de tomadores de decisão, como as audiências públicas, de institutos que se destinam a compensar déficits democráticos, como o amicus curiae, e que isso não cria nenhum problema para a legitimidade e o desempenho da jurisdição constitucional brasileira. 
De fato, o que se tem atualmente é uma aproximação funcional tão estreita entre audiências públicas e amicus curiae que parece que a única diferença relevante entre os institutos está nos diferentes caminhos pelos quais a sociedade como um todo pode se fazer ouvir no tribunal: ou por demanda ativa da corte ou por provocação ativa da sociedade ${ }^{21}$. Ou seja: ou o STF convoca a sociedade, ou a sociedade requer que seja ouvida pelo STF. Essa aproximação pode ser justificada por uma ênfase exagerada nos debates sobre a legitimidade democrática da atuação de um tribunal que exerce cada vez mais protagonismo na agenda política nacional; mas também por uma compreensão reducionista do processo decisório da corte, que encara (e deveria tratar) a superação de questões constitucionais como a solução de problemas de interpretação constitucional, i.e. questões que dizem respeito ao sentido de disposições constitucionais ou à concretização de seus princípios fundamentais. A ampla participação em audiências públicas no STF justificar-se-ia, assim, tanto pelas trilhas da política22 como de uma teoria normativa sobre a interpretação da Constituição democraticamente orientada. 23 Nos dois casos, o debate tradicional sobre a compatibilidade de atuação da corte na democracia ofusca e, assim, empobrece debates sobre a justificação epistêmica das suas decisões nos casos em que disputas científicas são cruciais para a determinação de respostas jurídicas para um problema.

Os efeitos positivos da maior permeabilidade da jurisdição constitucional a inputs da sociedade produzem, no entanto, efeitos perversos para o enfrentamento dos desafios reais impostos por problemas de fato aos ministros da corte. Reunir diversas opiniões não significa necessariamente obter mais informações. Da mesma forma, há limites para que a pluralidade signifique melhor compreensão. É nesse ponto que democracia e ciência, participação e conhecimento devem ser compreendidos como dois mundos separados.

Se a ideia de participação se justifica democraticamente pela possibilidade em si de o cidadão ser ouvido nos processos de formação da vontade estatal (e, assim, ter condições de influenciá-los), a produção de conhecimento especializado que marca o funcionamento da ciência depende da observância de normas e práticas de uma disciplina24. A diferença brutal entre os dois domínios está relacionada aos papéis que

21 No site institucional do STF, está previsto que entidades já admitidas na qualidade de amicus curiae, caso desejem participar da audiência pública, precisam inscrever-se, indicando especialista. Todavia, a fala de alguns ministros parece ser no sentido de aproximar ou mesmo equiparar a atuação enquanto amicus curiae e a participação na audiência pública. Tal é o caso do ministro Gilmar Mendes, como indicamos acima.

22 Para Barroso, as audiências públicas garantiriam um papel até representativo para o Supremo. Cf. BARROSO, Luís Roberto. A Razão sem Voto: o Supremo Tribunal Federal e o governo da maioria. Revista Brasileira de Políticas Públicas, Brasília, v. 5, Número Especial, 2015, p. 23-50, p. 40.

23 Neste caso, Häberle é a principal referência. V. HÄBERLE, Peter. Hermenêutica Constitucional - A Sociedade Aberta dos Intérpretes da Constituição: Contribuição para Interpretação Pluralista e "Procedimental" da Constituição. Revista Direto Público, nr. 60, vol. especial, p. 25-50, nov./dez. 2014.

24 POST, Robert. Democracy, Expertise, and Academic Freedom: A First Amendment Jurisprudence for the Modern State. New Haven: Yale University Press, 2013. 
o conteúdo das informações e as características de seus proponentes exercem para a aceitabilidade de respostas para problemas específicos. Enquanto a participação democrática é valiosa independentemente do conteúdo do que se diz, é fundamental investigar a qualidade do que se diz na ciência. Ainda, enquanto a justificação da participação da sociedade civil independe de características de quem emite uma opinião, os juízos de qualidade sobre o conteúdo de manifestações científicas costumam estar associados às credenciais de quem diz e ao respeito a certos procedimentos considerados pela comunidade científica necessários para comunicar certa mensagem. Assim, se é possível recorrer à metáfora do "abastecimento do mercado de ideias" que estrutura a compreensão da liberdade de expressão nos EUA25, o mercado de ideias relevante para a superação ou o reforço da legitimidade democrática de decisões estatais não é o mesmo mercado para o enfrentamento de questões de fato. Aquele é mais amplo, enquanto este é mais restrito. E deve ser assim, pois democracia e ciência funcionam em torno de objetivos, valores e práticas diferentes. No mundo da ciência,

[n]em tudo pode ser dito, nem todos podem falar e, principalmente, nem todas as falas têm igual valor. É claro que a ciência é uma prática falível e suscetível à corrupção; mas ela constitui, até hoje, a tentativa mais bem-sucedida de compreender objetivamente certos aspectos do mundo. A ciência não está - e é bom que não esteja - sujeita à construção social a partir de interesses e necessidades contingentes. Em um certo sentido, a ciência é uma violação à democracia26.

Em contraposição à ideia de legitimidade democrática, tão citada pelos Ministros do STF, destacamos a noção de competência democrática27. A competência democrática pode ser vista como um valor constitucional que protege as práticas sociais responsáveis pela produção e distribuição do conhecimento especializado, disciplinar - isto é, em oposição à chamada mera opinião. "O que é essencial não é que todos devam falar" afirma Post, "mas que tudo que valha a pena ser dito seja dito"28. Para que as decisões em uma democracia possam ser tomadas de forma inteligente, sobretudo no mundo de hoje em que o conhecimento está cada vez mais complexo e especializado, é preciso distinguir as ideias boas das ideias ruins, as proposições verdadeiras

\footnotetext{
25 Idem, p. 6.

26 HERDY, Rachel. Quando a ciência está em jogo, a democracia não importa. In Falcão, Joaquim; Arguelhes, Diego Werneck; Recondo, Felipe (orgs.). Onze Supremos: O Supremo em 2016. Belo Horizonte: Letramento, 2017, p. 46. Ver, ainda, HAACK, Susan. Irreconcilable Differences? The Troubled Marriage of Science and Law. In: and Truth in the Law. New York: Cambridge University Press, 2014. Evidence Matters: Science, Proof
}

27 POST, Robert. Democracy, Expertise, and Academic Freedom: A First Amendment Jurisprudence for the Modern State. New Haven: Yale University Press, 2013.

28 Idem. p. 36 
das falsas. Tal distinção implica, por sua vez, a possibilidade de se descriminar tanto o conteúdo daquilo que pode ser dito, como os sujeitos que podem falar. Interessam menos as garantias da igualdade e da liberdade de expressão daqueles que se candidatam a participar do discurso do que a garantia da boa informação. A garantia da boa informação, a qual tem como objetivo tornar as pessoas - os Ministros do STF, no caso - cognitivamente competentes para decidir, deve ser encarada como um objetivo antitético em relação às garantias de igualdade e liberdade de expressão no discurso público. Contudo, de forma paradoxal, esta mesma garantia de competência cognitiva, de produção e distribuição sistematizada do conhecimento, deve ser vista também como um requisito para a legitimidade na criação de políticas públicas ${ }^{29}$. Em suma, para que o discurso público seja guiado pelo valor da competência democrática, será necessário comprometer os valores da tolerância epistêmica. Os princípios da igualdade e da liberdade de expressão devem ser restringidos; mas esta restrição está justificada precisamente em nome da democracia.

Nesse contexto, o tribunal que recorre ao conhecimento especializado teria de se envolver em uma tarefa epistemológica difícil e controversa, que consiste em discernir ou discriminar a informação confiável da não-confiável. Como será demonstrado a seguir, o STF frequentemente ouve, em audiência pública, na qualidade de especialistas com autoridade e experiência na matéria, sob o pretexto da igualdade e pluralidade, participantes que não são especialistas nas questões discutidas; e participantes que, além disso, representam entidades diretamente interessadas na causa. A falta de autoridade epistêmica dos participantes e os interesses conflitantes que representam são aspectos que prejudicam o objetivo das audiências públicas de esclarecer questões de fato. Quando isto ocorre, há um reconhecimento implícito de que, na formulação de políticas públicas que envolvem conhecimentos específicos sobre questões de fato, importa menos a qualidade da informação do que a oportunidade de ouvir a opinião (fundamentada ou não) da "sociedade aberta dos intérpretes da constituição".

$O$ desenho de uma arena em que pessoas com as mais variadas formações apresentem ideias sobre questões de fato para os ministros do STF é estranho. Se o debate científico é compatível com a pluralidade e a saturação de ideias e experimentos, isso não significa que qualquer visão sobre determinado assunto é cientificamente relevante. No STF, há dois riscos permanentes. O primeiro é o de a solução de questões envolvendo a valoração jurídica de aspectos da realidade eliminar ou determinar a solução das questões de fato - e não o contrário. O segundo é o de disputas científicas serem superadas com base em razões não científicas. O tribunal poderá, nessa linha, não só basear decisões em meras opiniões, como abrir as portas para o chamado "lixo científico" (junk science): uma mistura de dados enviesados, inferências espúrias e

29 DEWEY, John. The Public and its Problems. Ohio University Press, 1927. 
malabarismos lógicos "costurados por pesquisadores cujo entusiasmo pela descoberta e pelo diagnóstico ultrapassa em muito suas habilidades"30. Soluções jurídicas para problemas de fato podem ser eventualmente baseadas em conjecturas ou especulações, e não em dados e consensos de uma comunidade de especialistas ${ }^{31}$. Em qualquer dos casos, como se nota, reunir mais informações não é necessariamente uma vantagem para a justificação de decisões jurídicas.

\section{UM BALANÇO SOBRE AS AUDIÊNCIAS PÚBLICAS}

\subsection{Questões metodológicas}

Os dados apresentados a seguir dizem respeito aos processos no âmbito dos quais foram convocadas e realizadas audiências públicas no STF. A primeira audiência pública ocorreu em abril de 2007; portanto, a pesquisa inicia-se a partir deste ano, muito embora a legislação, como visto ${ }^{32}$, preveja a possibilidade de realização de audiências públicas desde 1999. Informações a respeito da convocação da audiência pública, seu funcionamento e impacto na tomada de decisão foram levantados a partir da análise dos seguintes documentos: despachos convocatórios; vídeos no sítio eletrônico Youtube33; notas taquigráficas; informações constantes no sítio eletrônico do STF; e, quando publicados, votos dos ministros e acórdãos. Como alguns processos ainda não foram concluídos, os dados obtidos autorizam a sugestão de conclusões indicativas e parciais.

Vale observar que parte dos gráficos e das tabelas a seguir foram produzidas com base nas informações disponíveis até 2016. Algumas informações novas tornaramse disponíveis quando do momento da redação e finalização deste trabalho - como, por exemplo, os votos dos casos sobre amianto e ensino religioso em escolas públicas. Contudo, uma vez que a verificação dos achados e das correlações que levantamos demandariam tratamentos que excederiam o tempo que dispúnhamos para a presente divulgação, sob pena de comprometermos a acurácia dos dados apresentados e das nossas interpretações, optamos por não atualizar as tabelas e os gráficos com as novas informações. Indicamos o ano limite referente aos dados levantados nas legendas que

\footnotetext{
30 HUBER, Peter. Galileo's Revenge: Junk Science in the Courtroom. New York: Basic Books, 1991, p. 3. Além da denominada "junk science", reconhecemos igualmente o problema da entrada da "non-science" na corte, sem que se dê a devida atenção. Conforme criticado por Schauer: "Attempting to make litigation more scientific by keeping out bad science while not doing anything about the ubiquitous non-science that pervades the entire system might well result in a system that is less scientific and less reliable because it keeps out somewhat poor science and while letting the really poor science sneak in through the backdoor by not calling itself science at all". SCHAUER, Frederick. Can Bad Science Be Good Evidence? Neuroscience, Lie-Detection and Beyond. Cornell Law Review, New York, v. 95, n. 6, p. 1191-1219, 2009. p. 1217.

31 V. LEAL, Fernando. Para que servem as audiências públicas no STF? JOTA [16 jun. 2015]. Disponível em <https://jota.info/ artigos/para-que-servem-as-audiencias-publicas-no-Supremo-16062015>. Acesso em 19 set. 2017.

32 Supra, 2.1.

33 O canal do SUPREMO no sítio eletrônico Youtube está disponível em <https://www.youtube.com/user/SUPREMO>.
} 
subscrevem os gráficos e as tabelas; e as audiências públicas especificamente analisadas nas notas de rodapé. Na lista abaixo, foram integralmente analisadas as audiências públicas referentes ao temas 1 a 16; e parcialmente analisadas as audiências públicas referentes aos temas 18 a 22 :

1. pesquisas com células-tronco embrionárias (ADI n 3.510)

2. importação de pneus usados (ADPF $n^{\circ} 101$ )

3. interrupção de gravidez - feto anencéfalo (ADPF n० 54)

4. judicialização do direito à saúde (SL no 47, SL n 64, STA n 36, STA no 185, STA $n^{\circ} 211$, STA no 278, SS no 2.361, SS no 2.944, SS no 3.345, SS no 3.355)

5. políticas de ação afirmativa de acesso ao nível superior (ADPF no 186 e RE $n^{\circ}$ 597.285)

6. proibição de venda de bebidas alcoólicas nas proximidades de rodovias (ADI no 4.103)

7. proibição do uso de amianto (ADI no 3.937)

8. novo marco regulatório para a TV por assinatura no Brasil (ADI n 4.679, ADI $n^{\circ} 4.756$ e ADI no 4.747)

9. campo eletromagnético de linhas de transmissão de energia ( $R E n^{\circ}$ 627.189)

10. queimadas em canaviais (RE $n^{\circ} 586.224$ )

11. regime prisional (RE $n^{\circ} 641.320$ )

12. financiamento de campanhas eleitorais (ADI $n^{\circ} 4.650$ )

13. biografias não autorizadas ( $A D I n^{\circ} 4.815$ )

14. programa "Mais Médicos" (ADI n5.037 e ADI n ${ }^{\circ} 5.035$ )

15. alterações no marco regulatório da gestão coletiva de direitos autorais no Brasil (ADI n 5062 e ADI n5065)

16. internação hospitalar com diferença de classe no SUS (RE $n^{\circ} 581.488$ )

17. ensino religioso em escolas públicas (ADI $n \circ 4.439$ ),

18. uso de depósito judicial (ADI 5.072),

19. novo Código Florestal ( $A D I$ n ${ }^{\circ} 4.901$, ADI n$^{\circ} 4.902$, ADI n 4.903, ADI n 4.937),

20. armazenamento de perfis genéticos de condenados por crimes violentos ou hediondos (RE no. 973.837),

21. audiência pública simultânea sobre os arts. 10 , § $2^{\circ}$, e 12 , iii e iv, da lei no 12.965/2014 - Marco Civil da Internet (ADI n 5.527) e a suspensão do aplicativo Whatsapp por decisões judiciais no Brasil (ADPF no 403)

22. aplicabilidade do direito ao esquecimento na esfera civil, em especial quando esse for invocado pela própria vítima ou por seus familiares (RE 1.010.606). 
Foram levantados dados (i) referentes às audiências em si, (ii) trazidos pelos participantes das audiências durante suas exposições orais e (iii) pertinentes à tomada de decisão. Em cada uma dessas três subdivisões, buscamos uma série de indicadores, a saber: ministro responsável pela convocação da audiência; argumentos utilizados pelo ministro para a convocação da audiência; tempo conferido para cada participante; duração das audiências; existência de contraditório entre os participantes; equilíbrio na distribuição das posições dos participantes da audiência; indicação de perguntas por parte do ministro no despacho convocatório; referências ao papel das audiências públicas por parte de algum ator envolvido na audiência; referências ao papel dos amici curiae por parte de algum ator envolvido na audiência; ministros que acompanharam a audiência; argumentação dos participantes, especialmente quanto à apresentação de dados não técnicos; referências a possíveis perguntas dos despachos convocatórios e apresentação de dados em sentidos opostos; posição do participante em relação ao pedido da ação (concorda/discorda/não se posiciona); manifestações de ministros e outros atores durante a audiência pública; decisão do pleno (unânime/por maioria) e resultado do julgamento (deferimento/ deferimento parcial/ improcedência); decisão por ministro (deferimento/ deferimento parcial/ improcedência); referências, nos votos, ao papel das audiências públicas, dos especialistas e dos amici curiae; referências, nos votos, a autoridades externas (não participantes das audiências); referências às audiências em si nos votos (número e teor de citações gerais e específicas da fala de participantes); e concordância e discordância do posicionamento do participante citado frente ao pedido da ação.

A partir do conjunto de dados obtidos, selecionamos e correlacionamos alguns pontos que nos pareceram relevantes. Formulamos gráficos e tabelas para os seguintes tópicos:

Gráfico 1: Convocação de AP por ministro

Gráfico 2: Número de participantes por AP

Tabela 1: Manifestações de ministros e outros atores durante a AP

Tabela 2: Posicionamento dos participantes frente ao pedido da ação (por AP)

Gráfico 3: Posicionamento dos participantes frente ao pedido da ação (total)

Gráfico 4: Ministros presentes por número de AP realizada

Gráfico 5: Presença em AP por ministro

Gráfico 6: Presença dos ministros em AP em função da convocação

Gráfico 7: Referências às AP nos votos em função da presença dos ministros

Gráfico 8: Referências nos votos por ministro em função do número de AP convocadas

Gráfico 9: Posicionamento dos ministros frente às suas citações às AP

Gráfico 10: Número de citações às AP nos votos 


\section{Gráfico 11: Referências aos especialistas nos votos}

Diagrama 12: Distribução das audiências públicas por matéria

Todos os dados levantados e apresentados pretendem fornecer um panorama geral sobre o funcionamento real das audiências públicas no Supremo nos últimos dez anos, permitindo ilustrar as disfuncionalidades apontadas nas partes anteriores.

\subsection{O que dizem os dados}

O Gráfico 1 apresenta as diferenças de comportamento entre os ministros em termos de disposições para a convocação de audiências públicas. O ministro Luiz Fux foi quem mais fez uso desta prerrogativa. Cabe ressaltar que os dez ministros listados abaixo são os únicos que já convocaram audiências públicas desde a criação do instituto até a conclusão deste estudo. Todas as 22 audiências públicas convocadas até maio de 2017 foram analisadas.

\section{Gráfico 1 - Convocação de audiência pública por ministro34}

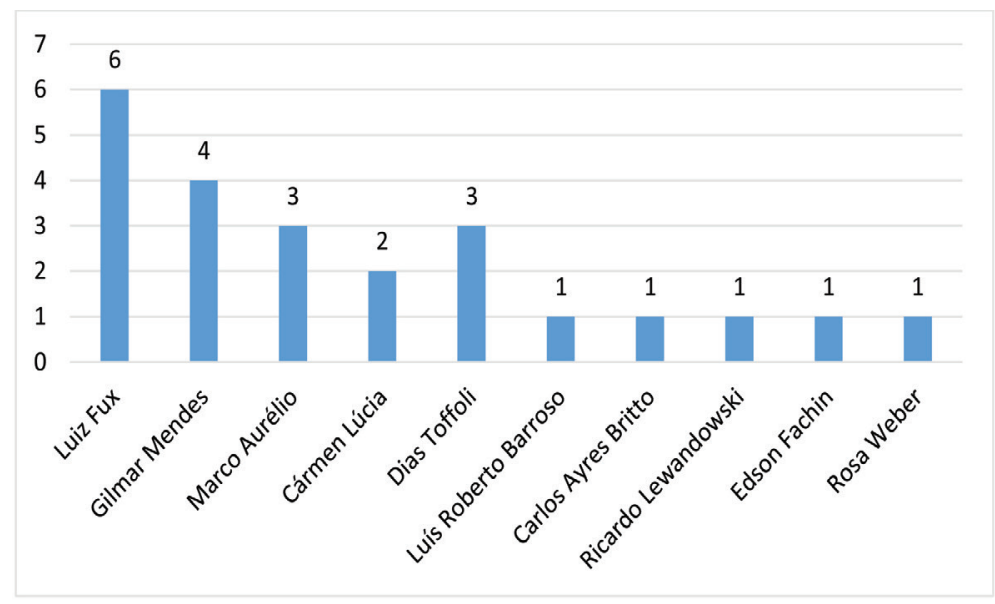

Fonte: STF. Elaboração própria (2017).

\footnotetext{
34 Cabe esclarecer que a contabilização de 23 convocações de audiências públicas frente à realização de apenas 22 audiências no total se justifica em função da convocação de uma audiência pública simultânea para discutir aspectos dos arts. 10 e 12, II e IV, da Lei n 12.965/2014 - Marco Civil da Internet (ADI 5.527, Rel. Min. Rosa Weber) - e a suspensão do aplicativo WhatsApp por decisões judiciais no Brasil (ADPF 403, Rel. Min. Edson Fachin). Haja vista que tanto a ministra Rosa Weber, quanto o ministro Edson Fachin convocaram audiência pública própria, com despachos convocatórios individuais e temas distintos, contabilizamos uma convocação de audiência pública para cada ministro, ainda que tenha havido posterior convocação e realização conjunta de uma mesma audiência para discutir os dois temas simultaneamente.
} 
O Gráfico 2 apresenta o número de especialistas ou expositores participantes por audiência pública. O recorte temporal deste gráfico é de 2007 a 2014. Há casos em que os representantes de uma mesma entidade habilitada a participar optaram por dividir o tempo concedido pelo ministro que presidiu a audiência; neste caso, contabilizamos o número total de pessoas que fizeram sustentações orais. Isto é, o critério adotado não consiste na contagem do número de entidades/expositores divulgados na lista de habilitados, mas sim do número de expositores que efetivamente estiveram presente e que se manifestaram na audiência. A fala dos próprios ministros e das autoridades ou partes que tenham feito considerações iniciais na audiência foram desconsideradas para efeitos desta análise.

\section{Gráfico 2 - Número de participantes por audiência pública}

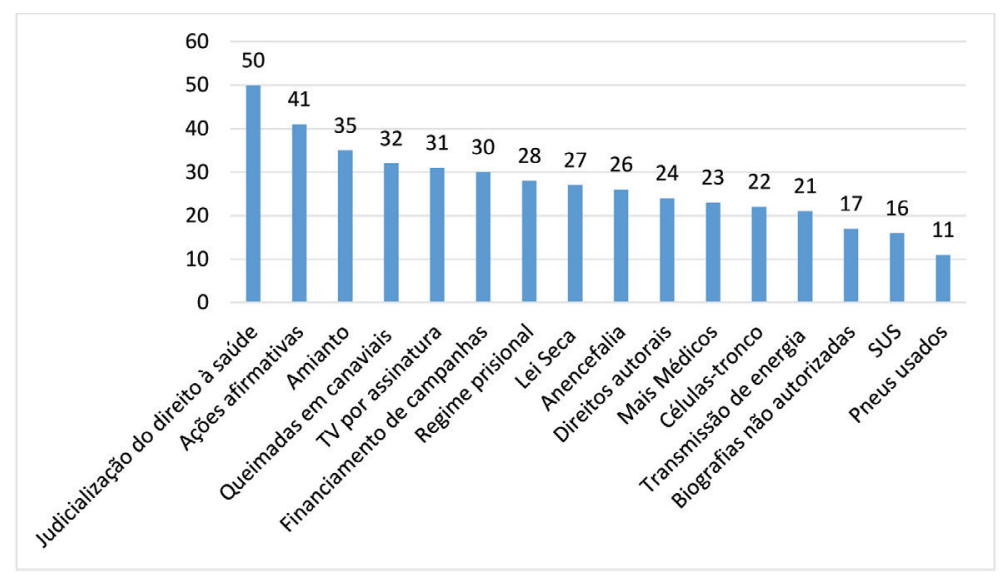

Fonte: STF. Elaboração própria (2016).

A Tabela 1 indica o número de manifestações de ministros e outros representantes de entidades durante as sustentações orais dos participantes. Empregamos os termos "manifestação" ou "intervenção" em referência à fala de qualquer ator - ministro, procurador, participante, membro da plateia etc. - durante a exposição de determinado participante da audiência pública. Esta manifestação pode ter ocorrido logo após o término de uma exposição ou ao final da audiência pública, quando há referência expressa à fala deste participante. As manifestações do próprio participante que estava fazendo a exposição em resposta às perguntas ou comentários feitos não foram consideradas. Cada nova manifestação foi contabilizada, ainda que determinado ator já tivesse se manifestado durante a fala do mesmo participante. Não foram considerados 
os comentários sobre o funcionamento de equipamentos ou demais questões operacionais, bem como os simples agradecimentos.

É possível perceber que o número de manifestações é frequentemente baixo ou mesmo nulo. Vale notar que a possibilidade de intervenção em si depende não só da participação próativa de um ou de alguns poucos ministros/entidades específicas, como da maneira como o ministro relator decide conduzir a audiência pública. No caso da audiência pública sobre anencefalia, por exemplo, o ministro relator Marco Aurélio permitiu ao advogado da parte, Luís Roberto Barroso, que formulasse questoes de clarificação. Sozinho, Barroso foi responsável por 51 intervenções durante a fala dos participantes. Já na audiência pública sobre campo eletromagnético de transmissão de energia, o ministro Dias Toffoli e o Suprocurador-Geral da República Mário Gisi mostraram-se bastante atuantes. Na audiência sobre pesquisas com células-tronco, por sua vez, o alto número de manifestações ocorreu em razão da atuação do ministro Carlos Ayres Britto, que estabeleceu um bloco de perguntas ao final da audiência.

Esta tabela é um indicador relevante da inexistência concreta de um debate público e do exercício do contraditório. Considerando a dupla função atribuída às audiências públicas, temos aqui uma dupla incoerência na prática do STF. Se, por um lado, a função das audiências públicas é de legitimação democática da jurisdição constitucional, não faz sentido restringir os debates entre os atores envolvidos 35 . Por outro lado, se a sua função é epistêmica, a supressão do debate é também um sinal de que o argumento de autoridade está sendo usado de modo falacioso. Neste caso, não é preciso sequer analisarmos o teor das manifestações em si; basta verificar a sua pouca ou nula frequência. $\mathrm{O}$ apelo à opinião do expert será sempre falacioso, constituindo um uso "dogmático" do argumento de autoridade, quando não são admitidos desafios ou questionamentos críticos 36 . Portanto, o número reduzido ou nulo de manifestações, resultante da restrição ao efetivo diálogo durante as audiências públicas, é por si só um indício do uso incoerente do instituto das audiências públicas, seja qual for a função a ele atribuída - política ou epistêmica ou ambas.

Para ilustrar mais essa incoerência, mencionamos a fala emblemática do ministro Marco Aurélio no caso da audiência pública sobre anencefalia. Quando o então

\footnotetext{
35 Essa é, por exemplo, uma característica conceitualmente atribuída, à luz de diferentes referências doutrinárias, às audiências públicas (ainda que o foco não fosse as audiências públicas no STF) no relatório de pesquisa "Potencial de Efetividade das Audiências Públicas do Governo Federal", publicado pelo IPEA em 2013. V. FONSECA, Igor Ferraz da; et al. Potencial de Efetividade das Audiências Públicas do Governo Federal. Programa de Pesquisa sobre Democracia e Participação do Instituto de Pesquisa Econômica Aplicada (IPEA), 2013, p. 14. Disponível em: <http://www.ipea.gov.br/participacao/images/pdfs/participacao/relatorio_potencial_efetividade.pdf. Acesso em 04/10/2017>.

36 WALTON, Douglas. Appeal to Expert Opinion: Arguments from Authority. Pennsylvania: Pennsylvania State University Press, 1997. O uso legítimo do argumento de autoridade não deve bloquear o acesso às razões de segunda ordem que justificam a atribuição da autoridade (e.g., credenciais do expert). Estas razões não se confundem com as razões de primeira ordem que são excluídas quando usamos o argumento de autoridade; i.e., as razões do próprio cientista (HARDWIG, John. Epistemic Dependence. The Journal of Philosophy, New York, v. 82, n. 7, p. 335-349, 1985; HERDY, Rachel. Dependencia epistémica, antiindividualismo y autoridade en el Derecho. Isonomía: Revista de Teoría y Filosofía del Derecho, Ciudad de México, n. 40, p. 119-146, abr. 2014.).
} 
advogado Barroso questionou a posição de um dos participantes quanto à existência de consenso científico, o ministro rebateu: "Não podemos partir para um debate propriamente dito. A oportunidade não é essa. [...] Pediria, também, em um apelo ao Doutor Luís Roberto Barroso, que evite colocações que possam sugerir o debate, a réplica, a tréplica e, portanto, a projeção no tempo destes trabalhos"37.

\section{Tabela 1 - Manifestações de ministros e outros atores durante a audiência pública}

\begin{tabular}{|c|c|c|}
\hline & Número de participantes & Total de manifestações \\
\hline Anencefalia & 26 & 81 \\
\hline Transmissão de energia & 21 & 72 \\
\hline Células-tronco & 22 & 8 \\
\hline Biografias não autorizadas & 17 & 7 \\
\hline Ações afirmativas & 41 & 4 \\
\hline SUS & 16 & 3 \\
\hline Lei Seca & 27 & 1 \\
\hline Mais Médicos & 23 & 1 \\
\hline Direitos autorais & 24 & 1 \\
\hline Financiamento de campanhas & 30 & 0 \\
\hline Queimadas em canaviais & 32 & 0 \\
\hline Pneus usados & 11 & 0 \\
\hline Judicialização do direito à saúde & 50 & 1 \\
\hline Regime prisional & 28 & 26 \\
\hline
\end{tabular}

Fonte: STF. Elaboração própria (2016).

Na Tabela 2 é possível observar o posicionamento dos participantes de cada audiência pública frente ao pedido da ação proposta perante o STF. Isto é, se os participantes posicionaram-se favorável ou contrariamente ao pedido postulado. Foi considerado o posicionamento expresso ou implícito dos participantes em relação ao pedido. Aqueles que não se posicionaram abertamente em relação ao pedido da ação ou cujo

37 BRASIL. Notas taquigráficas da audiência pública na Arguição de Descumprimento de Preceito Fundamental № 54/ DF. Disponíveis em: <http://www.stf.jus.br/arquivo/cms/processoAudienciaPublicaAdpf54/anexo/ADPF54_notas_dia_26808. pdf>, p. 13. Acesso em 02 out. 2017. 
posicionamento não restou claro a partir da sua fala foram contabilizados na categoria "indeterminado". A partir da leitura conjunta desta tabela com o Gráfico 3, na sequência, constata-se que a distribuição dos participantes entre os que concordam ou discordam do pedido é, em geral, equilibrada.

\section{Tabela 2 - Posicionamento dos participantes frente ao pedido da ação (por audiência)}

\begin{tabular}{|c|c|c|c|}
\hline & Concorda & Discorda & Indeterminado \\
\hline Anencefalia & 16 & 9 & 1 \\
\hline $\begin{array}{c}\text { Transmissão de } \\
\text { energia }\end{array}$ & 12 & 5 & 4 \\
\hline Células-tronco & 11 & 11 & 0 \\
\hline $\begin{array}{c}\text { Biografias não } \\
\text { autorizadas }\end{array}$ & 14 & 3 & 0 \\
\hline Ações afirmativas & 12 & 25 & 4 \\
\hline SUS & 3 & 12 & 1 \\
\hline Lei Seca & 5 & 20 & 2 \\
\hline Mais Médicos & 10 & 10 & 3 \\
\hline Direitos autorais & 11 & 12 & 1 \\
\hline $\begin{array}{c}\text { Financiamento de } \\
\text { campanhas }\end{array}$ & 14 & 11 & 5 \\
\hline $\begin{array}{l}\text { Queimadas em } \\
\text { canaviais }\end{array}$ & 17 & 7 & 8 \\
\hline Pneus usados & 6 & 5 & 0 \\
\hline $\begin{array}{l}\text { Judicialização do } \\
\text { direito à saúde }\end{array}$ & 12 & 17 & 21 \\
\hline Regime prisional & 5 & 16 & 7 \\
\hline
\end{tabular}

Fonte: STF. Elaboração própria (2016). 


\section{Gráfico 3 - Posicionamento dos participantes frente ao pedido da ação (total)}

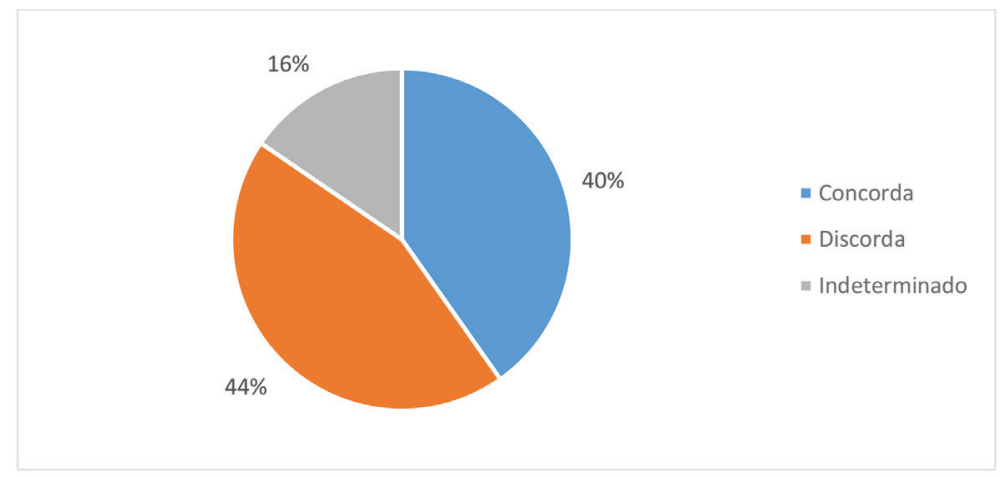

Fonte: STF. Elaboração própria (2016) ${ }^{38}$.

Os dados parecem refletir uma preocupação dos ministros em garantir uma "pluralidade da composição da audiência e dos pontos de vista a serem defendidos"39. Isto é, uma busca pela divisão equitativa dos posicionamentos dos participantes da audiência frente ao pedido da ação, o que seria uma forma de se evitar o favorecimento de quaisquer das partes. E tal forma de organização da audiência e admissão de participantes parece estar em consonância com o estabelecido no próprio RISTF de que (art. 154, II): "havendo defensores e opositores relativamente à matéria objeto da audiência, será garantida a participação das diversas correntes" 40 .

Há casos nos quais este propósito foi levado ao extremo ao se compartimentar a audiência em "blocos", cujas composições se deram com base nas correntes de pensamento ou perfil dos participantes. Mas, conforme já demonstrado por Vieira e Corrêa, tal funcionamento pode mostrar-se ineficiente. No caso da audiência pública realizada no âmbito da ADI 3.510 (células-tronco), os autores identificam que a divisão entre um bloco pela constitucionalidade e outro pela inconstitucionalidade pode ser prejudicial "porque, ao ser traçada uma linha definitiva entre os 'tipos' de participantes,

\footnotetext{
38 Dados referentes às seguintes audiências públicas: pesquisas com células-tronco embrionárias, importação de pneus usados, interrupção de gravidez - feto anencéfalo, judicialização do direito à saúde, políticas de ação afirmativa de acesso ao nível superior, lei seca - proibição de venda de bebidas alcoólicas nas proximidades de rodovias, campo eletromagnético de linhas de transmissão de energia, queimadas em canaviais, regime prisional, financiamento de campanhas eleitorais, biografias não autorizadas, programa "Mais Médicos", alterações no marco regulatório da gestão coletiva de direitos autorais no Brasil e internação hospitalar com diferença de classe no SUS.

39 Supremo Tribunal Federal. Despacho convocatório de audiência pública na Ação Direta de Inconstitucionalidade $\mathbf{n}^{\circ}$ 4.439/DF. Dispõe sobre o ensino religioso em escolas públicas. Disponível em <http://www.stf.jus.br/arquivo/cms/audienciasPublicas/anexo/Despacho_convocatorio_ENSINO_RELIGIOSO_EM_ESCOLAS_PUBLICAS.pdf>, p. 4. Acesso em 02 out. 2017. Critério evidenciado pelo ministro Luís Roberto Barroso para a admissão de participantes na audiência pública.

40 BRASIL. Regimento Interno do Supremo Tribunal Federal (STF). Brasília: STF, 2015. Disponível em <http://www.stf.jus.br/ arquivo/cms/legislacaoRegimentolnterno/anexo/RISTF.pdf> Acesso em 02 out. 2017.
} 
as manifestações dos mesmos também podem acabar confinadas em um modelo rígido"41. Além disso, observamos ainda que o contraditório entre os participantes poderia ser dificultado, haja vista que estes teriam menos possibilidades de expor questões técnicas contrárias ao posicionamento do outro "bloco". Nesse cenário de apresentação organizada (e, em alguns casos, maniqueísta) de diferentes pontos de vista e, ao mesmo tempo, de inibição de debates entre os especialistas, não é difícil imaginar como os ministros tendem a funcionar mais como árbitros de disputas científicas do que decisores bem informados sobre as visões e valorações da comunidade científica sobre questões de fato ${ }^{42}$. Tais críticas também podem ser extendidas à audiência pública sobre ensino religioso, na qual houve a divisão por perfis de participantes (representante de entidade religiosa ou especialista na área de ensino, por exemplo)43.

Finalmente, também foi objeto de levantamento a contabilização da presença dos ministros nas audiências públicas. Conforme o disposto no Gráfico 4, em nove audiências, praticamente a metade, havia apenas um ministro presente. Observa-se que, na prática, o ministro relator sempre comparece. Por vezes, o ministro presidente do STF também se faz presente para iniciar os trabalhos (sessão de abertura) e, não raro, retira-se da sessão logo após o seu pronunciamento. Na minoria dos casos, há outro(s) ministro(s) presentes.

\section{Gráfico 4 - Ministros presentes por número de audiências públicas realizadas}

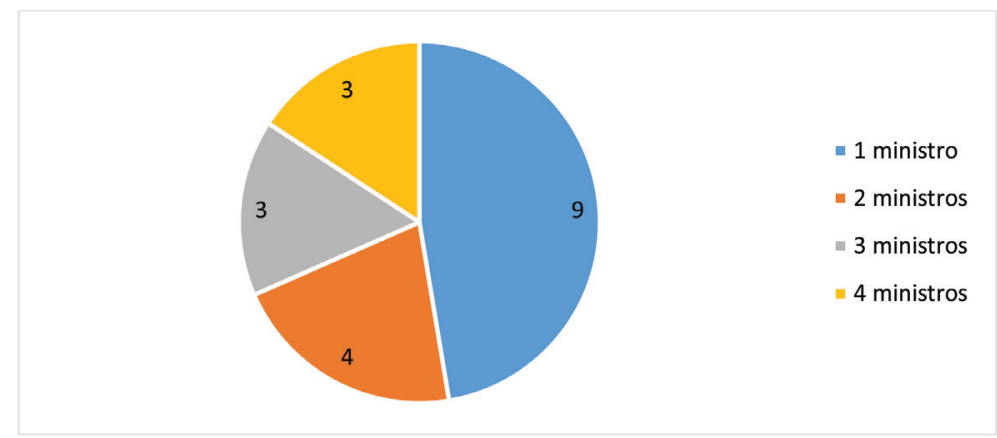

Fonte: STF. Elaboração própria (2017)44.

\footnotetext{
41 VIEIRA, José Ribas; CORRÊA, Letícia França. Audiência Pública Jurisdicional no Supremo Tribunal Federal. In: CARVALHO, Flávia Martins de; VIEIRA, José Ribas (Coord.). Desafios da Constituição: Democracia e Estado no Século XXI. Rio de Janeiro: UFRJ, 2011, p. 46.

42 Sobre esses riscos v. supra, 2.2 .

43 Cf. BRASIL. Vídeos da audiência pública na Ação Direta de Inconstitucionalidade n 4.439/DF. Dispõe sobre o ensino religioso em escolas públicas. Disponível em <http://www.stf.jus.br/arquivo/cms/audienciasPublicas/anexo/Links_Audiencia_publica_Ensino_religioso_nas_escolas_publicas.pdf >. Acesso em 02 out. 2017.

44 Dados relativos a todas as 19 audiências públicas realizadas até abril de 2017, quais sejam: pesquisas com células-tronco embrionárias, importação de pneus usados, interrupção de gravidez - feto anencéfalo, judicialização do direito à saúde, políticas de ação afirmativa de acesso ao nível superior, lei seca - proibição de venda de bebidas alcoólicas nas proximidades de rodovias, campo eletromagnético de linhas de transmissão de energia, queimadas em canaviais, regime prisional, financiamento de
} 
O Gráfico 5 indica os ministros que participaram das audiências públicas. Foram considerados como presentes os ministros que tenham comparecido por qualquer período de tempo no local em que as audiências públicas estavam sendo realizadas. Gilmar Mendes foi o ministro que mais esteve presente em audiências públicas em geral - participou de sete das dezenove audiências realizadas - e em audiências que não tenham sido por ele convocadas. O ministro compareceu a uma parte dessas audiências na qualidade de Presidente do STF para a sessão de abertura, retirando-se logo após.

A baixa frequência dos ministros pode estar em parte relacionada ao papel desempenhado pelo ministro relator no STF45, que comanda os trabalhos e participa ativamente das audiências públicas. A confiança no relator como o responsável pela coleta das informações e esclarecimentos necessários para a tomada de decisão parece ser um entendimento compartilhado pelos ministros em geral e que pode ser exemplificado a partir da fala do ministro Ricardo Lewandowski no seu voto no RE 586.224/SP (queimadas em canaviais):

[e]u vou acompanhar o excelente voto do Ministro Luiz Fux [relator], que não apenas examinou as questões constitucionais, infralegais, mas também mergulhou nas questões pragmáticas dessa questão importante que este Supremo Tribunal Federal está decidindo. E eu tenho certeza [de] que chegou a essa conclusão tendo em conta a audiência pública que fez, onde ouviu todas as partes interessadas ${ }^{46}$.

campanhas eleitorais, biografias não autorizadas, programa "Mais Médicos", alterações no marco regulatório da gestão coletiva de direitos autorais no Brasil, internação hospitalar com diferença de classe no SUS, proibição do uso de amianto, novo marco regulatório para a TV por assinatura no Brasil, ensino religioso em escolas públicas, uso de depósito judicial e novo Código Florestal. Critério de presença adotado neste estudo: foi contabilizado como presente o ministro que tenha comparecido por qualquer período de tempo no local em que a audiência pública estava sendo realizada, ainda que não a tenha acompanhado até o seu término.

45 Quanto ao papel desempenhado pelo ministro relator no STF, Virgílio Afonso da Silva ressalta a sua importância no processo decisório do tribunal, o que parece ser corroborado a partir da análise das audiências públicas. A partir de entrevistas realizadas com os ministros do STF, Silva afirma que, em geral, estes "[v]eem o papel do relator como decisivo na deliberação. Esse papel é traduzido por expressões como 'ele baliza todo o debate,' 'é uma posição preponderante', 'ele fixa a moldura do debate', 'é um ponto de partida para discussão'. Mesmo assim, há vozes discordantes sobre esse papel preponderante e também indicações de outros papéis decisivos do relator". SILVA, Virgílio Afonso da. "Um voto qualquer?" O papel do ministro relator na deliberação no Supremo Tribunal Federal. Revista Estudos Institucionais, v.1, n.1, 2015. Disponível em <https://www.estudosinstitucionais.com/REl/article/view/21>, p. 188. Acesso em 02 out. 2017. É importante salientar, no entanto, que tal preponderância do ministro relator no processo deliberativo do STF é limitada (especialmente nas decisões mais importantes do tribunal). Sobre o debate cf. ALMEIDA, Danilo dos Santos; BOGOSSIAN, Andre Martins. "Nos termos do voto do relator": considerações acerca da fundamentação coletiva nos acórdãos do STF. Revista Estudos Institucionais, v. 2, n. 1, 2016. Disponível em <https://www. estudosinstitucionais.com/REl/article/view/44>. Acesso em 02 out. 2017; SILVA, Virgílio Afonso da. O relator dá voz ao STF? Uma réplica a Almeida e Bogossian. Revista Estudos Institucionais, v. 2, n. 2, 2016. Disponível em < https://www.estudosinstitucionais.com/REI/article/view/81/104>. Acesso em 02 out. 2017.

46 BRASIL. Supremo Tribunal Federal. Recurso Extraordinário n 586.224/SP. Rectes. Estado de São Paulo e Sindicato da Indústria da Fabricação do Álcool do Estado de São Paulo - SIFAESP. Recdos. Câmara Municipal de Paulínia e Município de Paulínia. Relator: Min. Luiz Fux. Brasília, DF, 05 mar. 2015, p. 19. Disponível em <http://redir.stf.jus.br/paginadorpub/paginador.jsp?doc$T P=T P \& d o c \mid D=8399039>$, p. 68. Acesso em 02 out. 2017. 
Como esta fala do ministro Lewandowski sugere, a baixa frequência dos ministros às audiências públicas pode estar relacionada à deferência prestada ao relator do caso. A prática do tribunal parece ser a de os ministros prestarem, na verdade, uma dupla deferência aos relatores quando (i) não comparecem à audiência pública e (ii) não utilizam propriamente os argumentos nela apresentados em seus votos, optando por acompanhar o relator. Nesses casos, os ministros agiriam de tal forma com base em uma confiança no ministro relator, que teria participado da audiência, absorvido as informações levadas por especialistas sobre questões de fato (que podem envolver inclusive questões técnico-científicas) e repassado adequadamente tais informações - cruciais para a realização de inferências jurídicas e para a consequente tomada de decisão naquele caso concreto - para os demais ministros ${ }^{47}$.

Em outras palavras, os ministros parecem entender que a participação e coleta das informações a respeito do que foi discutido nas audiências públicas é uma função própria do ministro relator, sendo opcional para os demais. Comumente, os próprios relatores informam que irão repassar todas as informações colhidas na audiência pública para os outros ministros, que utilizarão os referidos dados nos seus julgamentos. Este é o caso da ministra Cármen Lúcia, que, durante a audiência pública sobre biografias não autorizadas, informou que a gravação da audiência seria entregue a todos os ministros "exatamente para que eles possam, tendo acesso a todos os dados, também se valer de tudo o que foi exposto aqui para a elaboração de seus votos. Claro que todos não podem estar presentes por outros afazeres, mas, de toda sorte, queria fazer esse registro" 48 . Se os ministros realmente assistem aos vídeos e/ou leem as notas taquigráficas das audiências para extrair as informações necessárias para a sua tomada de decisão, é algo que não pode ser averiguado empiricamente a partir da análise dos votos publicados e demais informações disponíveis. Todavia, fato é que a baixa frequência dos ministros às audiências públicas é evidente, bem como o baixo número de referências às audiências e/ou aos especialistas nos votos; e, ainda, que parece existir uma correlação entre esses dois aspectos, conforme demonstraremos no Gráfico 7 a seguir.

\footnotetext{
47 A baixa colegialidade e os baixos índices de deliberação que marcam o processo decisório da corte indicam intuitivamente que o papel do relator não é, de fato, tão importante em termos de influência dos votos dos demais ministros como o discurso dos ministros parece fazer crer. V. sobre o assunto SILVA, Virgílio Afonso. Deciding without deliberating. International Journal of Constitutional Law, v. 11, nr. 3, p. 557-584, 2013.
}

48 BRASIL. Supremo Tribunal Federal. Vídeos da audiência pública na Ação Direta de Inconstitucionalidade no 4.815/DF. Dispõe sobre as biografias não autorizadas. Disponível em <https://www.youtube.com/watch?v=p8B_UBERIhQ\&list=PLippyY19Z47snMTqOO3vtRdit5BeN6QVj>. Acesso em 26 out. 2016. Transcrição própria. 


\section{Gráfico 5 - Presença em audiências públicas por ministro}

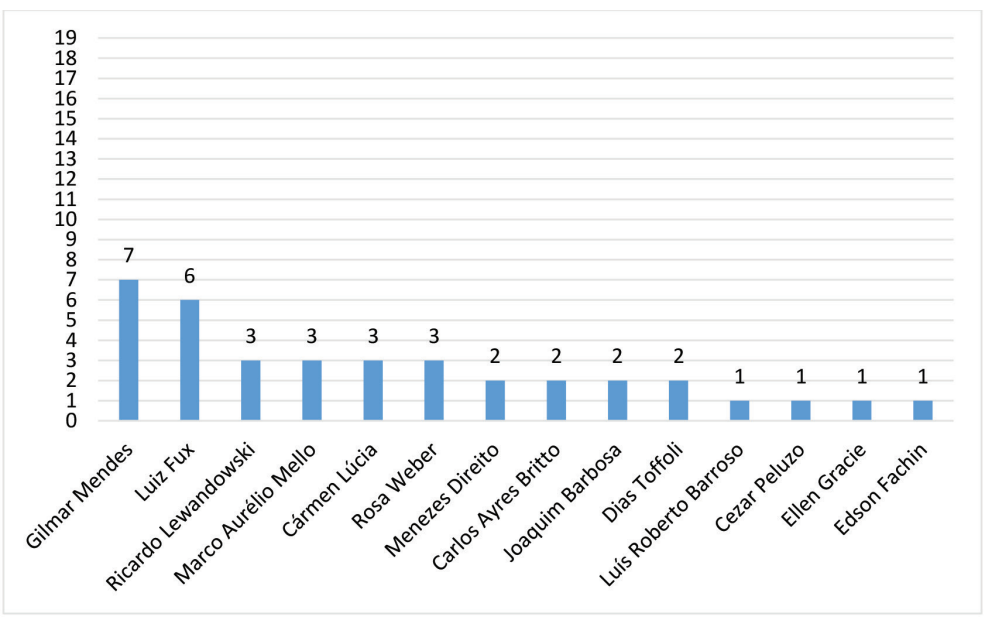

Fonte: STF. Elaboração própria (2016) 49

Além da presença total, no Gráfico 6, correlacionamos os dados a respeito do número de vezes que os ministros individualmente considerados estiveram presentes em audiências públicas com o número de vezes que as convocaram. É possível inferir que os ministros tendem a comparecer às audiências públicas que tenham sido por eles convocadas. O ministro Fux, por exemplo, apesar de ter uma presença comparativamente grande nas audiências públicas em geral (Gráfico 5), apenas compareceu àquelas que convocou (Gráfico 6). Isso nos leva a concluir que os ministros parecem entender que a participação em audiências públicas é um papel do relator do caso, sendo meramente opcional para os demais. Novamente, foram considerados como presentes os ministros que tenham comparecido por qualquer período de tempo no local em que as audiências públicas estavam sendo realizadas.

\footnotetext{
49 Dados relativos às seguintes audiências públicas: pesquisas com células-tronco embrionárias, importação de pneus usados, interrupção de gravidez - feto anencéfalo, judicialização do direito à saúde, políticas de ação afirmativa de acesso ao nível superior, lei seca - proibição de venda de bebidas alcoólicas nas proximidades de rodovias, campo eletromagnético de linhas de transmissão de energia, queimadas em canaviais, regime prisional, financiamento de campanhas eleitorais, biografias não autorizadas, programa "Mais Médicos", alterações no marco regulatório da gestão coletiva de direitos autorais no Brasil, internação hospitalar com diferença de classe no SUS, proibição do uso de amianto, novo marco regulatório para a TV por assinatura no Brasil, ensino religioso em escolas públicas, uso de depósito judicial e novo Código Florestal.
} 


\section{Gráfico 6 - Presença dos ministros em audiências públicas em função da convocação}

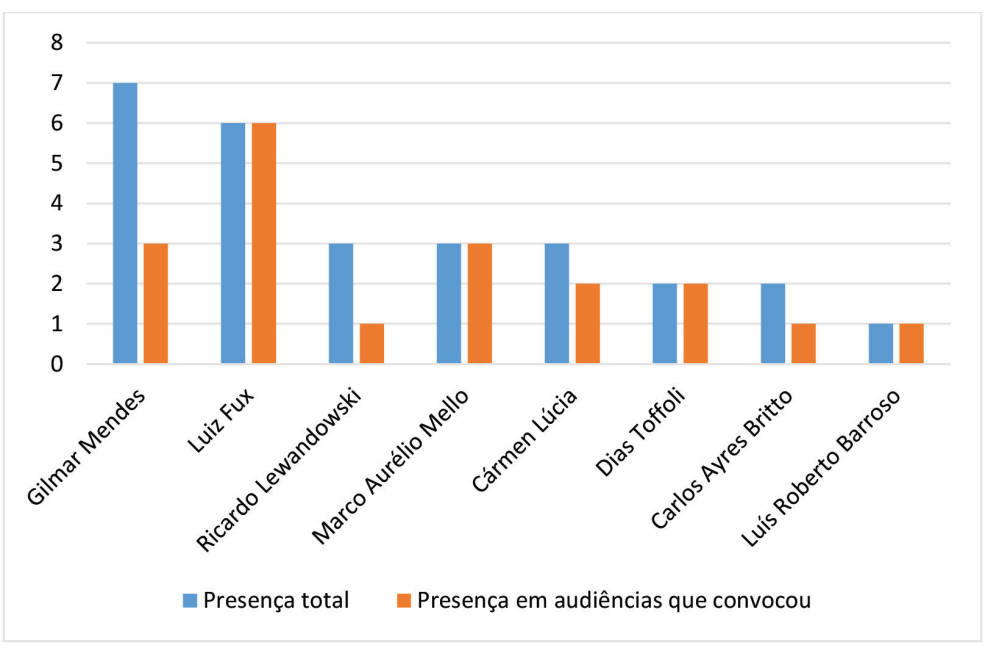

Fonte: STF. Elaboração própria (2017)50

No Gráfico 7, é possível correlacionar a presença dos ministros à audiência pública com a quantidade de referências feitas a elas em seus respectivos votos. Consideramos quaisquer citações, sejam elas genéricas, à audiência pública, ou concretas, aos especialistas participantes da audiência pública ou às entidades representadas. Quanto à presença, novamente foram considerados como presentes os ministros que tenham comparecido por qualquer período de tempo no local em que as audiências públicas estavam sendo realizadas.

Os dados deste gráfico devem ser interpretados à luz do número de votos publicados. O número total de referências feita por ministro pode ser afetado em função de um maior ou menor número de votos publicados, alterando os valores apresentados. Interessante destacar que os ministros Zavascki e Eros Grau nunca participaram de uma audiência pública; e, de modo correspondente, tampouco fizeram referências em seus respectivos votos. Esta baixa correlação entre ausência da audiência e ausência de referência no voto pode ser igualmente identificada em relação ao ministro Fachin, que compareceu a apenas uma audiência e sobre ela não teceu quaisquer considerações.

50 Dados relativos a todas as dezenove audiências públicas realizadas até abril de 2017 (v. nota 44 supra). 


\section{Gráfico 7 - Referências às audiências públicas em função}

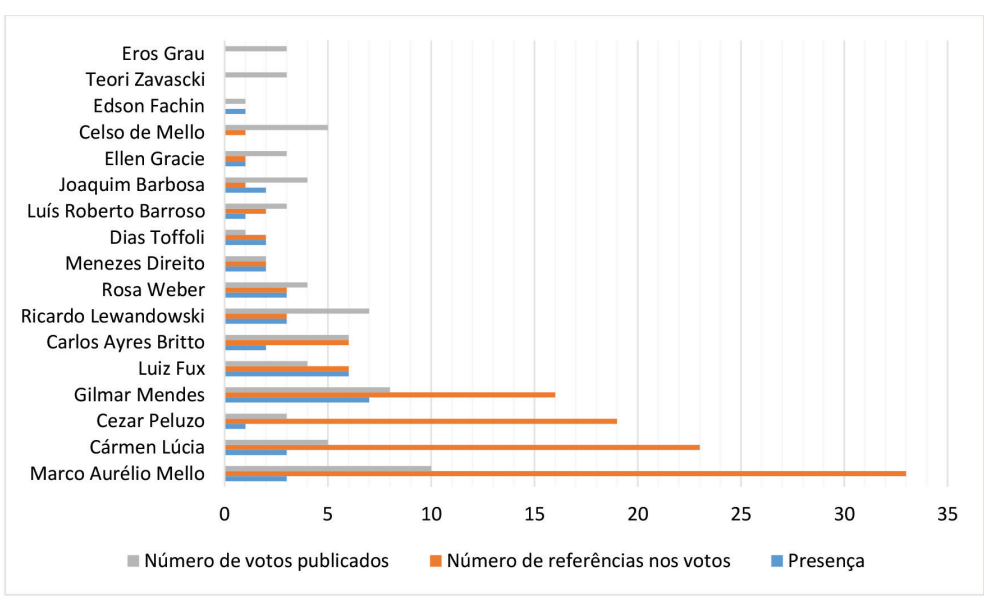

Fonte: STF. Elaboração própria (2016)51.

Como era de se esperar, identificamos ainda uma correlação entre o número de referências e as atuações dos ministros como relatores. No Gráfico 8, percebemos que os ministros tendem a fazer referências às audiências públicas em seus votos quando tenham sido responsáveis pela convocação da audiência pública. O ministro Marco Aurélio, por exemplo, é o que mais fez referências aos especialistas em seus votos. Todavia, das 33 referências que ele fez no total, 30 foram feitas em processos cuja audiência pública ele mesmo convocou 52 . Comparativamente, em relação aos demais processos cuja audiência não convocou, fez apenas 3 referências ao que foi dito pelos especialistas. Além da ausência corriqueira dos ministros nas audiências, o grande volume de trabalho dos gabinetes e a não leitura prévia do relatório, que costuma ser conhecido pelos demais ministros apenas na sessão de julgamento, podem explicar - ainda que em parte - o baixo número de referências às audiências públicas pelos ministros não relatores ${ }^{53}$.

\footnotetext{
51 Até outubro de 2016, apenas os ministros listados acima tinham votos publicados em processos envolvendo audiências públicas. Dados referentes aos seguintes processos: ADPF 54/DF (anencefalia); ADPF 101/DF (importação de pneus usados);

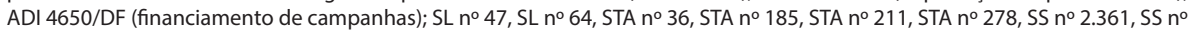
2.944, SS no 3.345, SS no 3.355 (judicialização do direito à saúde); ADPF 186/DF e RE 597.285/RS (ações afirmativas); ADI 3.510/ DF (células-tronco); ADI 4815/DF (biografias não autorizadas); RE 586.224/SP (queimadas em canaviais); RE 641320/RS (regime prisional) e ADI 3937/SP (amianto).
}

$52 \mathrm{O}$ ministro fez 14 referências no seu voto no âmbito do julgamento da ADPF 54/DF (anencefalia) e 16 no seu voto na ADI 3937/ SP (amianto). A audiência pública sobre o programa "Mais Médicos" não foi incluída nessa análise, pois nenhum voto havia sido publicado até a conclusão deste estudo (ADI n 5.037/DF e ADI n5.035/DF).

53 Conforme evidenciado por Virgílio Afonso da Silva a partir dos dados obtidos em entrevistas com ministros do STF: "Há ministros que relativizam o papel do relator. Uma causa citada é o volume de trabalho no STF. Nesse sentido, o ministro C afirmou: $\mathrm{Na}$ grande maioria dos casos, os ministros não leem o relatório, basicamente porque há muito serviço para ler, mas também pelo fato de que muitos relatórios são muito extensos [...]. Em outras palavras o relatório, na prática, acaba não exercendo a sua 


\section{Gráfico 8 - Referências em função do número de audiências públicas convocadas}

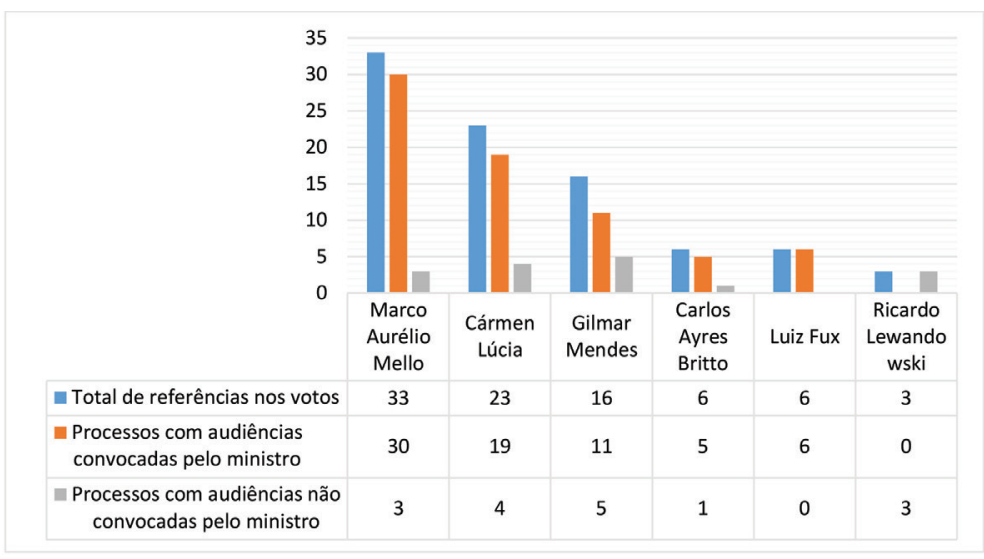

Fonte: STF. Elaboração própria (2016)54.

No Gráfico 9, verificamos que, quando os ministros fazem referência à audiência pública e citam participantes, em $57 \%$ dos casos eles concordam com o que foi dito pelo participante. Há, portanto, uma tendência de os ministros apresentarem informações que corroboram as hipóteses defendidas em seus votos. Esta tendência pode indicar um uso estratégico deliberado das manifestações dos participantes nas audiências públicas ou então mera influência de um viés de confirmação. Cumpre destacar ainda o grande número de casos (32\%) em que o participante não se posiciona claramente a respeito do pedido.

A concordância do ministro com o que foi dito na audiência pública foi constatada mediante indicação expressa pelo ministro e/ou através do contexto em que a referência foi feita. Em alguns casos, o participante não se posicionou ou não foi possível determinar o seu posicionamento. Tais casos foram classificados como "indeterminados".

função". SILVA, Virgílio Afonso da. "Um voto qualquer?" O papel do ministro relator na deliberação no Supremo Tribunal Federal. Revista Estudos Institucionais, v.1, n.1, 2015. Disponível em <https://www.estudosinstitucionais.com/REl/article/view/21>, p. 188-189. Acesso em 02 out. 2017. A partir dessa constatação, é plausível supor que os ministros de forma geral também não têm tempo hábil para assistir aos vídeos das audiências públicas, ler suas notas taquigráficas ou mesmo para ler os relatórios, nos quais normalmente consta um "resumo" dos principais argumentos apresentados pelos participantes da audiência pública. Este pode ser o motivo pelo qual os ministros fazem poucas referências às audiências em seus votos. $E$ isso pode evidenciar que os ministros não aproveitam a ocasião da audiência pública para esclarecer todas as suas dúvidas sobre questões que envolvam aspectos técnico-científicos, tendo que buscar informações em outras fontes (v. Gráfico 11, abaixo) ou deixando de embasar adequadamente seus votos ao não considerar tais questões complexas na sua tomada de decisão.

54 Dados referentes aos seguintes processos: ADPF 54/DF (anencefalia); ADPF 101/DF (importação de pneus usados); ADI 4650/

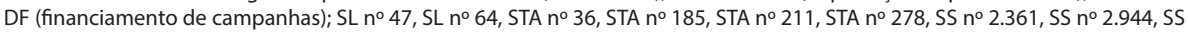
n 3.345, SS n 3.355 (judicialização do direito à saúde); ADPF 186/DF e RE 597.285/RS (ações afirmativas); ADI 3.510/DF (célulastronco); ADI 4815/DF (biografias não autorizadas); RE 586.224/SP (queimadas em canaviais); RE 641320/RS (regime prisional) e ADI 3937/SP (amianto). 


\section{Gráfico 9 - Posicionamento dos ministros frente às suas citações}

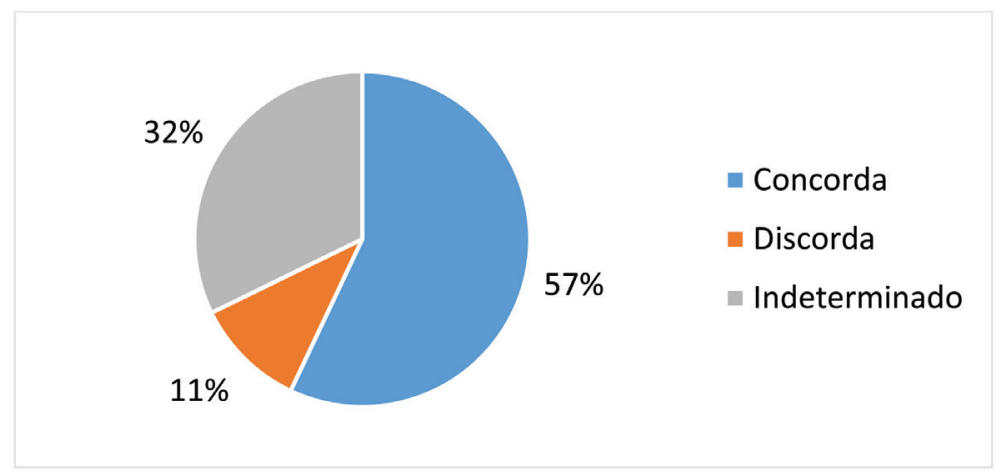

Fonte: STF. Elaboração própria (2016) ${ }^{55}$.

No Gráfico 10, observamos que os ministros (relatores ou não) que estiveram presentes, ainda que por um curto período de tempo, durante a realização da audiência, tendem a citá-las com maior frequência do que os ministros ausentes. Novamente, consideramos as citações diretas a participantes das audiências públicas e as referências gerais às audiências públicas. Os ministros presentes nas audiências públicas citam-nas em média 5,18 vezes mais do que os ministros ausentes. Além disso, o ministro relator tende a citar em média 10,8 vezes mais as audiências públicas em seus votos do que os demais ministros. Considerando-se que em geral o ministro relator é o responsável pela convocação da audiência e está sempre presente, inferimos que o fator "ser ou não ser relator" é mais relevante do que o fator "estar ou não estar presente". Todavia, comparando os ministros "não relatores e presentes" e os ministros "não relatores e ausentes", observamos que os primeiros fazem mais referências às audiências públicas em seus votos do que os segundos. A partir disso, conclui-se que ambos os fatores "relatoria" e "presença" são relevantes na medida em que interferem na maior ou menor citação das audiências públicas nos votos, tendo um impacto na tomada de decisão.

\footnotetext{
55 Dados referentes aos seguintes processos: ADPF 54/DF (anencefalia); ADPF 101/DF (importação de pneus usados); ADI 4650/

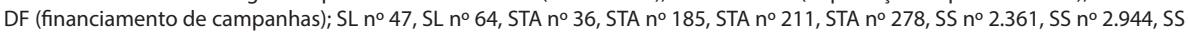
n 3.345, SS n 3.355 (judicialização do direito à saúde); ADPF 186/DF e RE 597.285/RS (ações afirmativas); ADI 3.510/DF (célulastronco); ADI 4815/DF (biografias não autorizadas); RE 586.224/SP (queimadas em canaviais) e RE 641320/RS (regime prisional). A decisão do pleno ainda não foi proferida na ADI 3937/SP (amianto), motivo pelo qual a mesma não foi incluída nesta análise.
} 


\section{Gráfico 10 - Número de citações das audiências públicas nos votos}

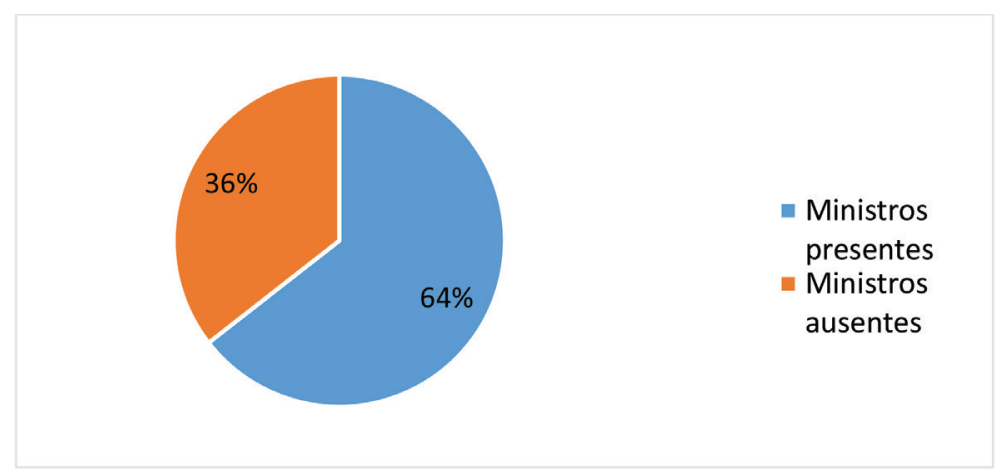

Fonte: STF. Elaboração própria (2016)56

No Gráfico 11 podemos observar o percentual de referências a especialistas externos (não participantes da audiência pública) em comparação ao percentual de referências às audiências públicas em geral nos votos. Consideramos o número de vezes em que foram feitas citações a participantes da audiência pública ou de argumentos nela apresentados em face da citação a especialistas externos. Não levamos em conta as diferenças nos perfis dos participantes da audiência pública na elaboração deste gráfico (especialista na área em questão ou não). Contudo, em relação aos especialistas externos, consideramos apenas as referências a autoridades específicas na matéria.

Percebemos que, do total de citações feitas, a maior parte $(66 \%)$ corresponde às audiências públicas. Ainda assim, um percentual relevante de citações (34\%) corresponde a especialistas externos. Essas referências externas são informações colhidas pelos próprios ministros ou seus assessores. Vale notar que as referências feitas na ADI 3.510/DF (células-tronco) não foram incluídas. Isso porque, o número de citações a especialistas externos feitas pelo ministro Menezes Direito (65) é muito superior ao número de citações feitas pelos outros ministros nos demais processos analisados. $\mathrm{O}$ ministro Menezes Direito cita mais especialistas externos em um único voto do que os outros ministros em todos os votos publicados. Caso incluíssemos os votos referentes a esta audiência pública, haveria uma distorção dos dados, dando a falsa impressão de que, em geral, os ministros citam mais especialistas externos do que participantes das audiências públicas. Embora essa conclusão esteja correta em termos absolutos, tal

\footnotetext{
56 Dados referentes aos seguintes processos: ADPF 54/DF (anencefalia); ADPF 101/DF (importação de pneus usados); ADI 4650/

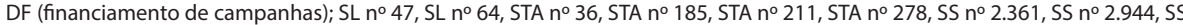
n॰3.345, SS n॰3.355 (judicialização do direito à saúde); ADPF 186/DF e RE 597.285/RS (ações afirmativas); ADI 3.510/DF (célulastronco); ADI 4815/DF (biografias não autorizadas); RE 586.224/SP (queimadas em canaviais), RE 641320/RS (regime prisional) e ADI 3937/SP (amianto). Todos os julgados nos quais audiências públicas foram convocadas e que possuíam ao menos um voto publicado até outubro de 2016 foram analisados.
} 
dado não reflete a prática do tribunal se consideradas as demais audiências públicas analisadas. Ainda assim, em relação a este voto do ministro Menezes Direito, é curioso notar que ele não apenas citou diversos estudos de especialistas externos, como indicou ter entrado em contato diretamente com um deles para o esclarecimento de uma questão controversa sobre o método de retirada da célula do embrião57.

A prática de se fazer referência a fontes externas ao processo para o embasamento de questões de fato não é um fenômeno novo, mas a sua maior frequência nos últimos anos tem alterado o caráter da argumentação jurídica58. Essa situação pode ser em parte explicada pelo imenso número de dados facilmente à disposição dos julgadores (big data). Os avanços na área de tecnologia da informação e comunicação basta o clique de um botão - permitem que os julgadores tenham acesso a toda sorte de dados para fundamentar suas decisões. Em relação a certas cortes que carecem de mecanismos e institutos para obter informações sobre fatos legislativos que orientam o julgamento de políticas públicas, como parece ser o caso da Suprema Corte dos Estados Unidos, esta prática pode estar justificada59. No caso do STF, contudo, uma vez que existe previsão institucional de um mecanismo específico para que os ministros consultem especialistas em questões de fato, é questionável a legitimidade das referências a especialistas externos.

O alto número de citações a especialistas externos por parte dos ministros pode ser possivelmente explicado por diversos fatores (não necessariamente excludentes entre si). Pode ser um sinal de que as informações fornecidas na audiência pública foram insuficientes para a tomada de decisão, sendo necessário que o ministro investigasse por si só e buscasse a sua própria fonte de informação técnico-especializada. Nesse caso, poderíamos questionar se os critérios de admissibilidade dos participantes e a organização da audiência têm se mostrado adequados para o propósito de suprir deficiências epistêmicas dos ministros. Pode ser ainda um indicador de que a audiência pública não é utilizada pelo ministro como fonte de obtenção de informação técnico -especializada a respeito do tema em questão, funcionando como um instituto retórico, meramente formal. Nesse caso, poderíamos questionar o uso legítimo do argumento de autoridade, especialmente quando ele não apresenta nenhuma outra fonte de dados ou quando a sua fonte é inconsistente com o que a maioria dos especialistas na área afirma60. Ou, talvez, o ministro tenha sido tão diligente em seu voto que não só

\footnotetext{
57 BRASIL. Supremo Tribunal Federal. Ação Direta de Inconstitucionalidade n 3.510/DF. Reqte. Procurador-geral da República. Reqdo. Congresso Nacional. Relator: Min. Carlos Ayres Britto. Disponível em <http://redir.Supremo.jus.br/paginadorpub/ paginador.jsp?docTP=TP\&doclD=583645\#87\%20-\%20AC\%D3RD\%C3O\%20-\%20improcedente>. Acesso em 27 out. 2016.

58 Ver SCHAUER, Frederick; WISE, Virginia. Nonlegal Information and the Delegalization of Law. Journal of Legal Studies, Chicago, vol. 29, n. 1, p. 495-515, 2000; LARSEN, Alisson Orr. Confronting Supreme Court Fact Finding. Virginia Law Review, Charlottesville, vol. 98, n. 6, p. 1255-1312, oct. 2012.

59 LARSEN, Alisson Orr. Confronting Supreme Court Fact Finding. Virginia Law Review, Charlottesville, vol. 98, n. 6, p. 12551312, oct. 2012.

60 WALTON, Douglas; ZHANG, Nanning. An Argumentation Interface for Expert Opinion Evidence. Ratio Juris, [s.l.], v. 29, n. 1,
} 
utilizou as informações apresentadas na audiência pública, como foi além. Este não parece ser o caso quando verificamos que o número total de referências às audiências públicas nos votos é baixo61. Nesta hipótese, no entanto, existe o risco da entrada descontrolada da junk science no processo decisório e, pior, de que o arbitramento feito pelos ministros entre as manifestações de especialistas e as opiniões pseudocientíficas se dê em favor dessas últimas.

\section{Gráfico 11 - Referências a especialistas nos votos}

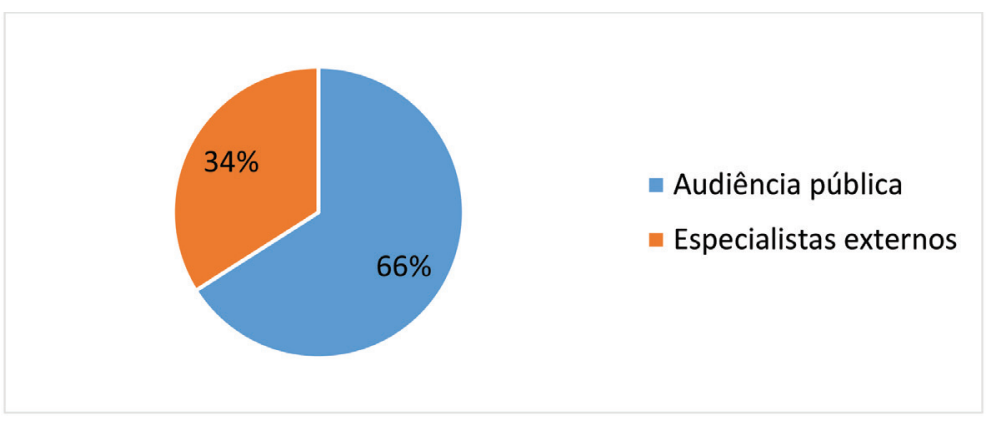

Fonte: STF. Elaboração própria (2016)62.

Encerramos com o Diagrama 12 abaixo, no qual distribuímos as audiências públicas de acordo com a matéria discutida entre dois polos: questões de fato e questões de direito. Por se tratar de uma distinção nem sempre fácil de ser estabelecida, a distribuição das audiências públicas foi projetada sobre um espectro, um continuum, considerando a maior ou menor proximidade do assunto discutido às categorias de fato e direito (diferença de grau). Sendo assim, as audiências cuja matéria se aproximavam mais de questões fáticas foram marcadas em azul, enquanto que as mais próximas da categoria jurídica foram indicadas em vermelho. Reconhecemos ainda a existência de uma "zona cinzenta", consubstanciada por audiências que ou englobavam tanto questões de fato como de direito em proporção similar ou nas quais não foi possível determinar se objeto eram questões de fato ou de direito. Em ambos os casos, é difícil a sua aproximação de qualquer um dos polos, motivo pelo qual essas audiências foram alocadas no centro do espectro.

\section{p. 59-82, 2016.}

61 Vide Gráfico 9 supra.

62 Os dados apresentados são referentes aos seguintes processos: ADI 3937/SP (amianto); ADPF 54/DF (anencefalia); ADPF 101/DF (importação de pneus usados); ADI 4650/DF (financiamento de campanhas); SL no 47, SL n 64, STA no 36, STA no 185, $\mathrm{STA}^{\circ} 211, \mathrm{STA}^{\circ} 278, \mathrm{SS} n^{\circ} 2.361, \mathrm{SS}^{\circ} 2.944, \mathrm{SS}^{\circ}$ 3.345, SS n 3.355 (judicialização do direito à saúde); ADPF 186/DF e RE 597.285/RS (ações afirmativas); ADI 4815/DF (biografias não autorizadas); RE 586.224/SP (queimadas em canaviais) e RE 641320/ RS (regime prisional). 
Cumpre esclarecer que este artigo não objetiva escalonar as audiências públicas, mas apenas indicar uma maior ou menor afinidade com um dos campos estabelecidos. Em função disso, as audiências foram distribuídas aleatoriamente dentro de cada campo do diagrama, não havendo qualquer hierarquização entre elas. Esta classificação das audiências entre os dois polos é, portanto, apenas sugestiva, e levou em consideração a maneira como a matéria a ser esclarecida é descrita no despacho convocatório do ministro relator. Não se considerou, portanto, o perfil dos participantes das audiências públicas. Fosse este aspecto levado em consideração, talvez nenhuma audiência pública pudesse ser classificada como sendo referente a matéria fática. Esta é uma observação importante; pois não é incomum, por exemplo, a constatação de que "especialistas" com qualificações políticas ou jurídicas participam de audiências públicas sobre matéria exclusivamente de fato ou técnica. Ou seja, as audiências públicas que tenham sido convocadas para o esclarecimento de matéria de fato foram assim classificadas à vista de suas respectivas descrições nos despachos convocatórios, ainda que os "especialistas" que tenham efetivamente participado não sejam experts na área específica relevante ou suportem algum tipo de conflito de interesse.

Reconhecemos que a distinção entre uma questão de fato e uma questão de direito é difícil de se manter com facilidade em todos os casos. Fato e valor (ou direito) são, afinal, noções vagas, que resistem a definições precisas. Vale recorrer aqui a um notório artigo sobre vagueza de Bertrand Russell63, que expõe a falácia do argumento que afirma que, se não podemos distinguir uma coisa de outra em todos os casos, então a distinção não faz sentido. Ora, ainda que não possamos dizer em relação a todos os homens quem é calvo e quem não é calvo, isto não significa que a calvície não seja um conceito cuja definição possua certa utilidade. Esta ideia foi apropriada por teóricos do direito como HLA Hart, que a empregou para a compreensão do conceito de "direito" e da pretensão de determinação das regras64. De modo análogo, para o propósito deste artigo, consideramos que a distinção entre questões de fato e questões de direito não pode ser satisfeita em todos os casos; mas que, ainda assim, faz sentido mantê-la. Ainda que os conceitos possam ser vagos, podemos identificar um número de casos claros classificáveis sob um rótulo ou outro; além, é claro, de um número de casos obscuros que podemos classificar em algum ponto intermediário no espectro.

As questões de fato podem ser de tipos distintos. Há fatos naturais e fatos sociais ou institucionais. De maneira esquemática, uma questão será considerada de fato quando ela for objeto de uma alegação que pretende estabelecer uma correlação entre dois eventos independentes da vontade humana; isto é, uma alegação dotada de objetividade. Alegações são fáticas porque podem ser verificadas objetivamente, ainda

63 RUSSEL, Bertrand. Vagueness. Australasian Journal of Philosophy, Sidney, vol. 1, n. 2, p. 84-92, 1923.
64 HART, H. L. A. The Concept of Law. 2. ed. Oxford: OUP, 1994. p. 124 e ss.. 
que de modo apenas probabilístico. A título exemplificativo e com base em questões discutidas nas audiências públicas sobre proibição do uso de amianto e políticas de ação afirmativa de acesso ao ensino superior, poder-se-ia extrair que a constatação aqui colocada de forma meramente hipotética - de que o amianto é um mineral altamente cancerígeno e que não há meios de utilizá-lo de forma segura seria um fato natural. Por outro lado, seria um fato social que negros e pardos são menos de $10 \%$ dos médicos engenheiros e dentistas brasileiros, mas quase $70 \%$ dos garimpeiros, carpinteiros e ambulantes do país. Tais questões diferem daquelas denominadas "de direito" ou "valorativas", que são objeto de uma alegação que envolve um juízo do preferível, a respeito de valores.

As audiências públicas buscam esclarecer questões de fato com o objetivo exclusivo de proferir uma decisão jurídica, que possui conteúdo moral (valorativo) ou político. Logo, para além de a distinção entre fato e valor ser vaga e de existirem distintos tipos de fato, questões de fato podem ser utilizadas como premissas de argumentos moral ou politicamente sensíveis. Contudo, isso não significa que elas percam a sua natureza fática. Quando se alega que "o diagnóstico da anencefalia é altamente confiável" ou que "a anencefalia é uma condição para a qual não há tratamento", estas alegações continuam a ser referentes a questões de fato, ainda que se acrescente à linha de argumentação acima a alegação de que "mulheres grávidas de fetos com anencefalia devem poder interromper a gestação". Portanto, embora, em certo sentido, fatos e valores estejam entrelaçados na argumentação jurídica - no exemplo acima, a afirmação de que "mulheres grávidas de fetos com anencefalia devem poder interromper a gestação" terá maior capacidade de persuasão se estiver apoiada na premissa fática que afirma que "bebês que nascem com anencefalia não são capazes de sobreviver fora do útero" - isso não implica desconsiderar a natureza fática das questões que são (ou pelo menos deveriam ser) discutidas em audiência pública.

\section{Diagrama 1 - Distribuição das audiências públicas por matéria}

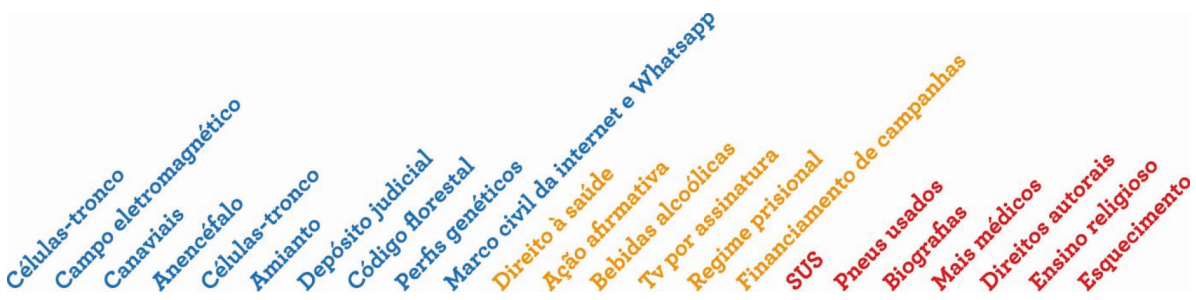

Fonte: STF. Elaboração própria (2017).

Como o Diagrama 12 indica, as audiências públicas têm sido frequentemente convocadas para a discussão de assuntos que são clara e exclusivamente valorativos. 
Este foi o caso, como já dito, da audiência pública sobre biografias não autorizadas. Dentre as questões discutidas, estava a possibilidade de o sujeito da biografia que se sentir ofendido pedir a exclusão de trecho(s) da obra. Ocorreria, neste caso, uma violação à liberdade de expressão do artista? Ora, esta é uma pergunta de natureza estritamente jurídica, que depende dos valores que queremos proteger. Evidentemente, há casos de difícil classificação e que envolvem - com expressividade similar - tanto questões fáticas quanto questões valorativas. Na audiência sobre o programa "Mais Médicos", por exemplo, discutiu-se temas como se a contratação de mais médicos para atuar na rede pública é eficaz na melhoria do atendimento à população carente. Há certamente aspectos técnicos envolvidos; mas a questão é própria da área de políticas públicas. Nesses casos, em que questões de valor são discutidas por "especialistas" em audiências públicas, podemos supor que o instituto esteja a ser utilizado de forma retórica. No final das contas, quem são os especialistas em matéria valorativa senão os próprios ministros do STF? A opinião dos "especialistas" parece servir precipuamente para aumentar o poder persuasivo de seus próprios argumentos; não servem a um propósito instrutório ou de esclarecimento.

\section{CONCLUSÃO}

Os dez anos de audiências públicas no Supremo revelam mais problemas do que vantagens para o processo decisório da corte. É verdade que a ampla participação de diferentes atores, na esteira do argumento da abertura democrática da jurisdição constitucional, pode atribuir ao instituto um papel simbólico relevante para a sociedade brasileira, ao possibilitar que certas vozes possam se fazer ouvir e certas pautas possam, em uma arena especial, ressoar com mais impacto no debate público. Mas essa é só uma hipótese. O que se tem de fato é que a consolidação desse espaço pretensamente democrático não veio sem custos altos para o funcionamento da jurisdição constitucional. Eles estão todos atrelados à disfuncionalidade real das audiências públicas na corte.

O instituto, que parece ter sido concebido para suprir carências epistêmicas dos ministros, reduziu-se a um foro em que convivem, em pé de igualdade e sem critérios claros de diferenciação, opiniões desinformadas com posições de especialistas. Com isso, sobra desorientação para a justificação epistêmica das decisões. Ademais, como os dados apresentados revelam, não há na prática critérios para a convocação de audiências públicas e para a definição de quem está habilitado para delas participar, há baixos níveis de interação e confronto entre os participantes, presença reduzida de ministros, baixa incorporação das audiências nas decisões dos ministros e usos das falas dos participantes nos votos como indícios de confirmações de crenças ou hipóteses preexistentes, o que tende a revelar uso míope ou estratégico. Dado o atual contexto, 
se, por um lado, é empiricamente incerto que as anunciadas vantagens trazidas pela compreensão democrática das audiências públicas se realizaram na prática, por outro, esses dez primeiros anos de funcionamento do instituto já trazem problemas suficientes para se questionar sua real utilidade.

Nesse cenário de disfuncionalidade epistêmica e utilidade democrática questionável, as audiências públicas deixam de servir ao principal propósito que justificaria a sua existência na jurisdição constitucional brasileira, já dotada de mecanismos para lidar com os déficits democráticos do Supremo. Se a solução de questões constitucionais depende de conhecimentos sobre questões de fato, a funcionalidade das audiências públicas estaria localizada na sua aptidão para permitir transições controladas entre as incertezas do direito e da ciência. 65 Nesse sentido, as audiências públicas serviriam para garantir maior confiabilidade para as decisões baseadas em juízos sobre fatos proferidos pelos ministros, como os que envolvem, por exemplo, a determinação do potencial cancerígeno de fibras de amianto; a viabilidade da vida extrauterina do feto anencefálico; a identificação dos efeitos da radiação eletromagnética para a saúde das pessoas, e as consequências de uma eventual redução do campo eletromagnético para o fornecimento de energia; e a mensuração dos reais efeitos que a ingestão de álcool pode causar em condutores de veículos.

Em todos esses casos, transições descontroladas entre o direito e a ciência aumentam exponencialmente as incertezas relacionadas à decisão jurídica, pois podem, no limite, colocar juízes como árbitros desinformados de disputas científicas. A prática do Supremo sugere que esse é quase sempre o caso. No melhor cenário, juízes são chamados a lidar com a "competição entre peritos, teorias e métodos academicamente certificados e dignos de deferência epistêmica"66. No pior, juízes podem simplesmente sustentar respostas jurídicas para problemas científicos com base em conjecturas, especulações, afirmações sem base metodológica ou tudo o que está compreendido no rótulo junk science. Para lidar com essas dificuldades decorrentes da interdisciplinaridade na decisão jurídica, as audiências públicas representariam uma peça que, juntamente com regras de distribuição de ônus e standards de prova, comporiam a engrenagem necessária para que o ingresso de evidências científicas na jurisdição constitucional brasileira ocorresse de maneira estável, controlada e com menor complexidade do ponto de vista do próprio direito.67 As audiências públicas, assim, desempenhariam um papel fundamental de redução de complexidade no tratamento de evidências científicas na adjudicação. Reduzidas a um simples mecanismo de participação de especialistas e

\footnotetext{
65 SCHUARTZ, Luis Fernando. Interdisciplinaridade e Adjudicação: Caminhos e descaminhos da ciência do direito. Texto Disponível em: <http://bibliotecadigital.fgv.br/dspace/bitstream/handle/10438/2174/TpD\%20008\%20-\%20Schuartz\%20-\%20 Interdisciplinaridade\%20e\%20adjudica\%E7\%E3o.pdf?sequence=1>. Acesso em 04/10/2017.

66 Id., p. 30.

67 Id., p. 5.
} 
não especialistas, transmutam-se, porém, em fontes de mais incerteza e imprecisão na tomada de decisão jurídica.

\section{REFERÊNCIAS}

BRASIL. Ação Direta de Inconstitucionalidade n 3.510/DF. Reqte. Procurador-geral da República. Reqdo. Congresso Nacional. Relator: Min. Carlos Ayres Britto. Disponível em <http://redir.stf. jus.br/paginadorpub/paginador.jsp?docTP=AC\&docID=611723>. Acesso em 03 out. 2017.

Despacho convocatório de audiência pública na Ação Direta de Inconstitucionalidade n 4.439/DF. Dispõe sobre o ensino religioso em escolas públicas. Disponível em <http:// www.stf.jus.br/arquivo/cms/audienciasPublicas/anexo/Despacho_convocatorio_ENSINO_RELIGIOSO_EM_ESCOLAS_PUBLICAS.pdf>. Acesso em 02 out. 2017.

Lei $\mathbf{N}^{\circ} \mathbf{9 8 6 8 / 9 9}$. Dispõe sobre o processo e julgamento da ação direta de inconstitucionalidade e da ação declaratória de constitucionalidade perante o Supremo Tribunal Federal. Sancionada em 10 de novembro de 1999. Disponível em <http://www.planalto.gov.br/ccivil_03/leis/ L9868.htm> Acesso em 31 maio 2017.

Lei No 9882/99. Dispõe sobre o processo e julgamento da arguição de descumprimento de preceito fundamental, nos termos do § 10 do art. 102 da Constituição Federal. Sancionada em 03 de dezembro de 1999. Disponível em <http://www.planalto.gov.br/ccivil_03/leis/19882.htm> Acesso em 31 maio 2017.

Notas taquigráficas da audiência pública na Ação Direta de Inconstitucionalidade n 3.937/SP. Dispõe sobre a proibição do uso de amianto. Disponível em <http://www.Supremo. jus.br/arquivo/cms/ProcessosAudienciasPublicasAcoesAmianto/anexo/Transcricoes_Audiencia_sobre_Amianto_Texto_consolidado.pdf>, p. 486. Acesso em 26 set. 2017.

Notas taquigráficas da audiência pública nas Ações Diretas de Inconstitucionalidade n 4901, 4902, 4903 e 4937. Dispõe sobre o Novo Código Florestal. Disponível em <http:// www.Supremo.jus.br/arquivo/cms/audienciasPublicas/anexo/TranscriesNovoCdigoFlorestal. pdf>. Acesso em 21 set. 2017.

Notas taquigráficas da audiência pública na Arguição de Descumprimento de Preceito Fundamental No 54/DF. Disponíveis em: <http://www.stf.jus.br/arquivo/cms/processoAudienciaPublicaAdpf54/anexo/ADPF54_notas_dia_26808.pdf>. Acesso em 02 out. 2017.

Recurso Extraordinário n 586.224/SP. Rectes. Estado de São Paulo e Sindicato da Indústria da Fabricação do Álcool do Estado de São Paulo - SIFAESP. Recdos. Câmara Municipal de Paulínia e Município de Paulínia. Relator: Min. Luiz Fux. Brasília, DF, 05 mar. 2015, p. 19. Disponível em <http://redir.stf.jus.br/paginadorpub/paginador.jsp?docTP=TP\&docID=8399039>, p. 68. Acesso em 02 out. 2017. 
Regimento Interno do Supremo Tribunal Federal (STF). Brasília: STF, 2015. Disponível em <http://www.stf.jus.br/arquivo/cms/legislacaoRegimentolnterno/anexo/RISTF.pdf> Acesso em 20 set. 2017.

Vídeos da audiência pública na Ação Direta de Inconstitucionalidade no 4.439/ DF. Dispõe sobre o ensino religioso em escolas públicas. Disponível em <http://www.stf.jus.br/ arquivo/cms/audienciasPublicas/anexo/Links_Audiencia_publica_Ensino_religioso_nas_escolas_publicas.pdf>. Acesso em 02 out. 2017.

Vídeos da audiência pública na Ação Direta de Inconstitucionalidade n 4.815/DF. Dispõe sobre as biografias não autorizadas. Disponível em<https://www.youtube.com/watch?v=p8B_UBERIhQ\&list=PLippyY19Z47snMTqOO3vtRdit5BeN6QVj>. Acesso em 26 out. 2016.

ARGUELHES, Diego Werneck e LEAL, Fernando. Por que só maconha? In: Joaquim Falcão, Diego Werneck Arguelhes e Felipe Recondo (Org.). O Supremo em 2015. Rio de Janeiro: Escola de Direito do Rio de Janeiro da Fundação Getulio Vargas, 2016, p. 331-334.

BARROSO, Luís Roberto. A Razão sem Voto: o Supremo Tribunal Federal e o governo da maioria. Revista Brasileira de Políticas Públicas, Brasília, v. 5, Número Especial, 2015, p. 23-50.

BOGOSSIAN, Andre Martins. "Nos termos do voto do relator": considerações acerca da fundamentação coletiva nos acórdãos do STF. Revista Estudos Institucionais, v. 2, n. 1, 2016, pp. 263-297. Disponível em <https://www.estudosinstitucionais.com/REl/article/view/44>. Acesso em 02 out. 2017.

CARVALHO, Flávia Martins de. Audiências Públicas no Supremo Tribunal Federal: uma alternativa democrática? Dissertação (Mestrado em Direito) - Universidade Federal do Rio de Janeiro, Centro de Ciências Jurídicas e Econômicas, Faculdade de Direito, 2011.

DAVIS, Kenneth Culp. An Approach to Problems of Evidence in the Administrative Process. Harvard Law Review, Cambridge, v. 55, n. 1, p. 402-?, 1941-42.

DEWEY, John. The Public and its Problems. Ohio University Press, 1927.

FONSECA, Igor Ferraz da; et al. Potencial de Efetividade das Audiências Públicas do Governo Federal. Programa de Pesquisa sobre Democracia e Participação do Instituto de Pesquisa Econômica Aplicada (IPEA), 2013, p. 14. Disponível em: <http://www.ipea.gov.br/participacao/images/ pdfs/participacao/relatorio_potencial_efetividade.pdf. Acesso em 04/10/2017>.

HÄBERLE, Peter. Hermenêutica Constitucional - A Sociedade Aberta dos Intérpretes da Constituição: Contribuição para Interpretação Pluralista e "Procedimental" da Constituição. Revista Direto Público, nr. 60, vol. especial, p. 25-50, nov./dez. 2014.

HAACK, Susan. Irreconcilable Differences? The Troubled Marriage of Science and Law. In:

Evidence Matters: Science, Proof and Truth in the Law. New York: Cambridge University Press, 2014. 
HARDWIG, John. Epistemic Dependence. The Journal of Philosophy, New York, v. 82, n. 7, p. 335349, 1985.

HART, H. L. A. The Concept of Law. 2. ed. Oxford: OUP, 1994.

HERDY, Rachel. Dependencia epistémica, antiindividualismo y autoridade en el Derecho. Isonomía: Revista de Teoría y Filosofía del Derecho, Ciudad de México, n. 40, p. 119-146, abr. 2014.

HERDY, Rachel. Quando a ciência está em jogo, a democracia não importa. In: FALCÃO, Joaquim; ARGUELHES, Diego Werneck; RECONDO, Felipe (orgs.). Onze Supremos: O Supremo em 2016. Belo Horizonte: Letramento, 2017.

HUBER, Peter. Galileo's Revenge: Junk Science in the Courtroom. New York: Basic Books, 1991.

LACOMBE, Margarida; LEGALE, Siddharta; JOHANN, Rodrigo F. As Audiências Públicas no Supremo Tribunal Federal nos modelos Gilmar Mendes e Luiz Fux: a legitimação técnica e o papel do cientista no laboratório de precedentes. In: VIEIRA, José Ribas, VALLE, Vanice Lírio do, MARQUES, Gabriel Lima (Orgs.). Democracia e suas Instituições. Rio de Janeiro: Imo's, 2014.

LARSEN, Alisson Orr. Confronting Supreme Court Fact Finding. Virginia Law Review, Charlottesville, vol. 98, n. 6, p. 1255-1312, oct. 2012.

LEAL, Fernando. Para que servem as audiências públicas no STF? JOTA [16 jun. 2015]. Disponível em <https://jota.info/artigos/para-que-servem-as-audiencias-publicas-no-Supremo-16062015>. Acesso em 19 set. 2017.

LEAL, Fernando. Os Impactos dos planos econômicos e a encruzilhada do Supremo. In: FALCÃO, Joaquim; ARGUELHES, Diego Werneck; RECONDO, Felipe (orgs.). Onze Supremos: O Supremo em 2016. Belo Horizonte: Letramento, 2016, p. 92-95.

PINTO, Henrique Motta; ROSILHO, André Janjácomo. Qual é a função das audiências públicas do STF: a legitimidade democrática ou a legitimidade técnica? Sociedade Brasileira de Direito Público, 2009.

POST, Robert. Democracy, Expertise, and Academic Freedom: A First Amendment Jurisprudence for the Modern State. New Haven: Yale University Press, 2013.

RUSSEL, Bertrand. Vagueness. Australasian Journal of Philosophy, Sidney, vol. 1, n. 2, p. 84-92, 1923.

SCHAUER, Frederick. Can Bad Science Be Good Evidence? Neuroscience, Lie-Detection and Beyond. Cornell Law Review, New York, v. 95, n. 6, pp. 1191-1219, 2009.

SCHAUER, Frederick; WISE, Virginia. Nonlegal Information and the Delegalization of Law. Journal of Legal Studies, Chicago, vol. 29, n. 1, p. 495-515, 2000.

SCHUARTZ, Luis Fernando. Interdisciplinaridade e Adjudicação: Caminhos e descaminhos da ciência do direito. Texto Disponível em: <http://bibliotecadigital.fgv.br/dspace/bitstream/ 
handle/10438/2174/TpD\%20008\%20-\%20Schuartz\%20-\%20Interdisciplinaridade\%20e\%20adjudica\%E7\%E3o.pdf?sequence=1 >. Acesso em 04/10/2017.

SILVA, Virgílio Afonso da. O relator dá voz ao STF? Uma réplica a Almeida e Bogossian. Revista Estudos Institucionais, v. 2, n. 2, 2016, pp. 648-669. Disponível em <https://www.estudosinstitucionais.com/REl/article/view/81/104>. Acesso em 02 out. 2017.

SILVA, Virgílio Afonso da. "Um voto qualquer?" O papel do ministro relator na deliberação no Supremo Tribunal Federal. Revista Estudos Institucionais, v.1, n.1, 2015, pp. 180-200. Disponível em <https://www.estudosinstitucionais.com/REl/article/view/21>. Acesso em 02 out. 2017.

VALLE, Vanice Regina Lírio do et al. Audiências públicas e ativismo: diálogo social no STF. Belo Horizonte: Fórum, 2012.

VESTENA, Carolina Alves. Audiências públicas: diagnóstico empírico sobre os limites da participação social. Revista Brasileira de Estudos Constitucionais - RBEC, Belo Horizonte, ano 6, n. 24, p. 973-1020, out./dez., 2012.

VIEIRA, José Ribas; CORRÊA, Letícia França. Audiência Pública Jurisdicional no Supremo Tribunal Federal. In: CARVALHO, Flávia Martins de; VIEIRA, José Ribas (Coord.). Desafios da Constituição: Democracia e Estado no Século XXI. Rio de Janeiro: UFRJ, 2011.

WALTON, Douglas. Appeal to Expert Opinion: Arguments from Authority. Pennsylvania: Pennsylvania State University Press, 1997.

WALTON, Douglas; ZHANG, Nanning. An Argumentation Interface for Expert Opinion Evidence. Ratio Juris, [s.I.], v. 29, n. 1, p. 59-82, 2016. 